\title{
The Proposal for a Common European Sales Law And the Convention on the International Sale of Goods: Friends or Foes?
}

\author{
Caroline Calomme
}

\section{Introduction}

In October 2011, the European Commission proposed the introduction of an optional European contract law to improve the functioning of the internal market.' Upon adoption, the Regulation on a Common European Sales Law (CESL) would become available to parties involved in cross-border sale transactions within the European Economic Area (EEA). ${ }^{2}$ By removing the current barriers, the objective of the instrument is to encourage European Union (EU) trade for both consumers and businesses, more specifically the small and medium-sized enterprises (SMEs). ${ }^{3}$ Nevertheless, the future of this new legal regime strongly depends on its utility to the parties concerned due to its voluntary optin nature. In other terms, the CESL will only succeed in eliminating the trade barriers as long as companies actually make use of this alternative legal system. ${ }^{4}$ This ambitious proposal shares many components with the well-established United Nations Convention on the Sale of Goods (CISG) adopted in 1980. Drafted by the United Nations Commission on International Trade (UNCITRAL), the Convention established a default legal regime for international commercial sale contracts. ${ }^{5}$ Similarly to the purpose of the CESL, UNCITRAL wished to bring about legal certainty and reduction of transaction costs. ${ }^{6}$

$\operatorname{COM}(2011) 635$ final, Art. 1(2).

CESL, p.8-11; Artt. 3-5 CESL; JURI Report February 2013, Issue No 2, p.8.

3 Art. 7 CESL; JURI 2013, p.8.

4 See also: UEAPME 2012, p.14; Heidemann 2012, p. 1126; N. Kornet 2012; Compare O. Ben-Shahar 2013, p.5.

5 United Nations Commission on International Trade Law, '1980 - United Nations Convention on Contracts for the International Sale of Goods (CISG)'.

6 UNCITRAL-CISG; Art. 1(2) CESL; Recitals 2-4 CESL. 
As 24 out of the $28 \mathrm{EU}$ Member States are contracting parties to the CISG, one perceives immediately the potential rivalry between the two legislative texts. ${ }^{7}$ Whereas this intergovernmental instrument focuses on contracts concluded between businesses regardless of their size ${ }^{8}$, the commercial scope of the European instrument requires one of the parties to be an SME. ${ }^{9}$ At first, this restriction could potentially reduce the scope overlap between the European instrument and its international counterpart. However, this category of businesses represents more than $99 \%$ of all EU businesses..$^{10}$ This inherent conflict may affect the likelihood of the CESL to be relied upon in business-to-business (B2B) transactions, upsetting the Commission's goal. On the contrary, companies may also replace the CISG in Europe, disturbing the attempts at international harmonisation. Instead of competing, the two legislative instruments could after all become complementary and learn from each other in the pursuit of this common goal, i.e. the removal of trade barriers.

This essay examines the relationship between the proposal for a Common European Sales Law and the Convention on the International Sale of Goods in B2B transactions and its future outcome on the law applicable to international commercial transactions: friends or foes? In order to do so, the analysis is comprised of six elements. The first section asks what threat the legal relationship between the two instruments poses. The second section evaluates how and to which extent business behaviour plays a role in the reliance on optional instruments. The next section inspects the level of achievement of the CISG from a diplomatic, legal and business perspective. Subsequently, the consequences of the European instrument on the legal environment are explored. Next, a series of examples illustrate whether the relationship between the two instruments is one of competition or of cooperation. Lastly, the future prospects for both instruments are looked at. In the end of this research, it is submitted that the CISG will enhance the chances of success of the CESL in the long term even though it is likely to affect its popularity for commercial transactions in the short term. Reversely, the CESL will pose a threat to the CISG in the beginning but it will progressively encourage the modernisation of international trade law instruments.

7 UNCITRAL - CISG Status.

8 Art. 1 of the United Nations Convention on the International Sale of Goods, 11 April 1980, Vienna (hereafter CISG).

9 Art. 7 CESL. 


\section{The threat posed by the Convention on the International Sale of Goods}

The first section provides a concise description of the scope, the content and the legal interaction between the two instruments to illustrate the sources of conflict. Political compromise has played a significant role in the shaping of the CISG and this is very likely to occur with the CESL proposal as well. For this reason, a substantive comparison of the documents would be limited to a pure academic exercise at this stage since the CESL is a mere proposal that still needs to be negotiated upon."

\subsection{Scope}

As the title of the Convention suggests, the international instrument is applicable to sale of moveable goods contracts between contracting parties having their place of business in a state party to the Convention under Art. 1(1)(a) CISG. ${ }^{12}$ In addition, it also applies if private international law points towards the law of a state party to the Convention under Art. 1(1)(b) CISG. The remainder of Chapter I specifies further exclusions. Particularly, 'goods bought for personal, family or household use' are excluded if there was either actual or constructive knowledge of that fact under Art. 2(a) CISG. In other terms, the CISG regulates B2B transactions whereas consumer contracts fall outside of the scope of application. In theory, it is however allowed to opt into the CISG for consumer sales as long as mandatory national provisions on consumer protection are maintained. ${ }^{13}$ Lastly, its territorial scope covers 24 out of the current 28 European Member States. ${ }^{14}$

According to Art. 5 CESL, the material scope covers the sale of goods, as well as the supply of digital content and related services. ${ }^{15}$ Whether the inclusion of digital content goes further than the scope of the CISG depends on the interpretation of the term 'good', which is not defined in the treaty itself. ${ }^{16}$ According to Art. 4 CESL, those contracts must be of a cross-border nature and the habitual residence of one of the parties must be situated

\footnotetext{
11 See Webster 22-10-2012, p.3; the drafting of the CISG (infra, section VI (2) \& (5)); Maastricht University Course on European Contract Law where a live simulation of those future negotiations has been held.

15 See the definitions under Art. $2(h),(j) \&(m)$ CESL.

16

See also: U. Magnus 2003, p.3.

Magnus 2012, p.231.

UNCITRAL - CISG Status.

I. Schwenzer 2012, p. 459-46o.
}

The Proposal for a Common European Sales Law And the Convention on the International Sale of Goods: Friends or Foes? 
in a Member State. The instrument is also intended to cover the entire EEA territory. ${ }^{17}$ The proposal intends to cover business-to-consumer $(\mathrm{B} 2 \mathrm{C})$ transactions but also $\mathrm{B} 2 \mathrm{~B}$ transactions when at least one of the parties is an SME on the basis of Art. 7 CESL.

\subsection{Content}

The substantive provisions of the CESL resemble very closely those of the CISG.${ }^{18}$ The B2B provisions are even qualified as identical. ${ }^{19}$ The structure of the instruments also appears similar. ${ }^{20}$ This convergence may be explained by the freedom of contract that lies at the heart of the CISG, the Principles of European Contract Law (PECL), the Draft Common Frame of Reference (DCFR) and now the CESL. ${ }^{21}$ In contrast, the CESL covers matters such as pre-contractual information duties, defects of consent, unfair contract terms and mandatory rules in favour of SMEs, which are absent from the CISG. ${ }^{22}$ The Convention is indeed designed for the 'basic and most frequent type of commercial transaction'23 and tt is confined to rules on formation, interpretation, rights and obligations of the parties and remedies. ${ }^{24}$ In Art. 4 CISG, issues of validity and property law consequences are explicitly excluded. At first sight, the CESL could therefore be considered as an asset since it is aimed at covering 'the whole lifecycle of the contract'.25 Unfortunately, the following issues are excluded from both instruments at this stage: validity of penalties, illegality, immorality, capacity, representation and property law related issues. ${ }^{26}$

The Convention on the International Sale of Goods counts 101 articles whereas the current proposal for a Common European Sales Law reaches 186 articles. Often compared by the amount of articles, the two instruments differ greatly once the word count related to the substantive provisions is looked upon. It appears that the CISG counts less than 9,000 words and the CESL more than 26,000 words. ${ }^{27}$ This is partly because the CESL

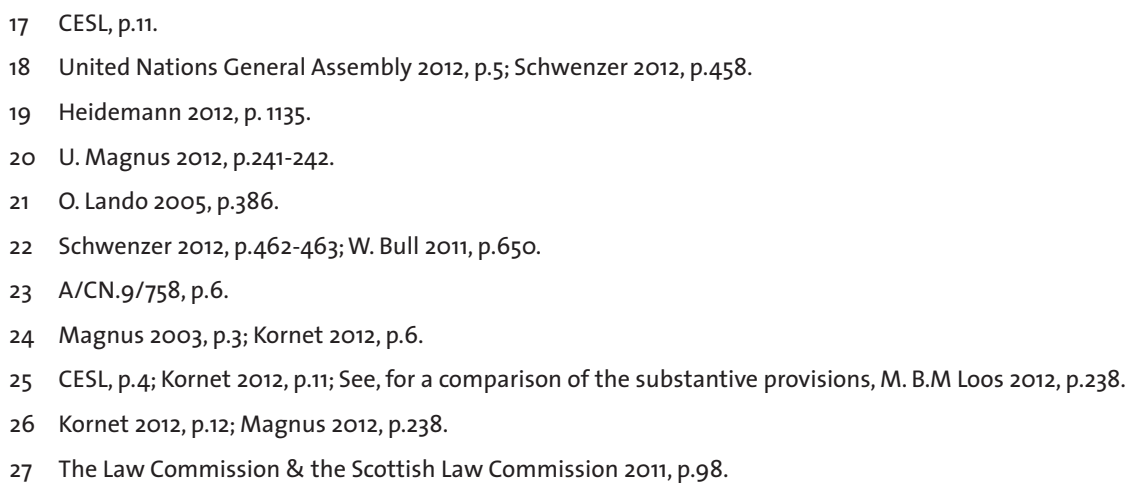


wished to include definitions whereas the CISG does not. Even though the legal certainty might be higher in the CESL due to its detailed drafting, the CISG might offer a better trade instrument to work with. As a matter of fact, businesses need to transform those provisions into standard contracts. Moreover, the opponents of the CESL refute that length adds to legal certainty and defend that it leads to even more confusion. ${ }^{28}$ The CESL is more thorough but this might have negative consequences if its intended use is 'simple' contracts. ${ }^{29}$ Nonetheless, the CESL already provides the businesses with workable documents in the annexes. ${ }^{30}$

\subsection{Legal relationship}

Before the publication of the Commission's proposal, the German professor Magnus had envisaged various options as to the legal relationship that would exist between the CISG and a European Contract law. ${ }^{31}$ His third example referred to hypothetical optional rules, which would enjoy a lower status than the CISG due to their non-binding nature..$^{32}$ Later, the Commission has found a balance by adopting rules only binding upon the parties wishing to be bound by them. ${ }^{33}$ Unfortunately, the scope chosen makes it difficult to identify a hierarchical order based on the lex specialis reasoning between the CESL and the CISG as the one already existing between the international instrument and the national systems, according to which the CISG takes precedence because of its specialisation. ${ }^{34}$ In the EU Member States, the CISG prevails over national rules of contract law.35 In that sense, both instruments function as 'a second national regime'. ${ }^{36}$ In practice, opting into CESL amounts to a choice within national law falling under Rome I rather than a choice for a national law. ${ }^{37}$ Since the two instruments might conflict with each other, the relationship between the two instruments must be clear. According to the recital 25 of the CESL, a choice for CESL automatically excludes the application of the CISG because it implies the will of the parties to opt-out. Contrarily,

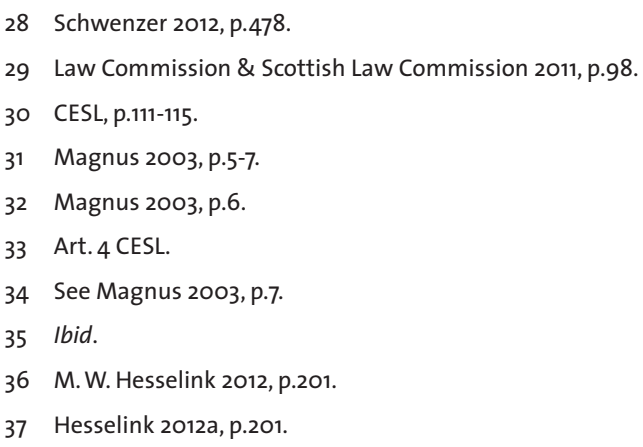


scholars deny the power of a choice of instrument under Art. 8 CESL to lead automatically to an exclusion of the CISG. ${ }^{38}$ According to Art. 6 CISG, 'the parties may exclude the application of this Convention or, subject to article 12, derogate from or vary the effect of any of its provisions'. Therefore, parties may opt-out of the CISG but this is determined by the CISG jurisprudence and not by the CESL. ${ }^{39}$ Art. 8 CISG determines when there has been consent of the parties, including consent to exclude the CISG. $4^{\circ}$ The CISG case law established that both express and implicit exclusions are allowed but it is in the interest of the parties to be clear about the governing law. ${ }^{41}$

\section{The implications of optional instruments}

The optional nature of the proposal for a Common European Sales Law places the faith of this European initiative in the hands of the parties. First, this section briefly explains the optional nature of both the Common European Sales Law and the Convention on the International Sale of Goods in order to show the key role played by the end-users, i.e. businesses. In the second part, the nature of businesses is put into perspective next to the available data in an attempt to shed light on the relation between businesses and contract law.

\subsection{Optional trade instruments}

\subsubsection{Convention on the International Sale of Goods}

According to Art. 6 CISG, the parties can opt out of the Convention on the International Sale of Goods. They can either exclude it entirely or select certain provisions as long as they do not derogate from the mandatory provisions as required by Art. $12 \mathrm{CISG}$. The term 'opt-out' fits conveniently in a discussion on the opt-in system of the CESL but the CISG can better be conceived as a default regime. ${ }^{22}$ In other terms, it applies automatically between trading partners in the contracting states if the conditions are met, unless action

\footnotetext{
38 Hesselink 2012a, p.195. 
is taken. ${ }^{43}$ In addition, a business situated in a non-contracting state or businesses in contracting states opting out of the CISG will fall back on the same instrument if they opt for the national law of a country that is a contracting state to the Convention. ${ }^{44}$

Interestingly, not only can private parties deviate from the CISG but such exclusion is also allowed for the contracting states themselves. Two or more states may also opt out of the international agreement for the contract of sales of goods concluded among business from those states under Art. $94 \mathrm{CISG}$. This exclusion is possible if they have 'the same or closely related legal rules on matters governed by this Convention'. The Scandinavian countries have already made use of this option such as to apply their already very similar sales law to those contracts. ${ }^{45}$ Finally, the CISG also knows an opt-in function for those countries that have not ratified the Convention. In the European Union, companies carrying out business from the United Kingdom, Ireland, Portugal and Malta can opt into the Convention under Art. 1(1)(b) CISG. ${ }^{46}$

\subsubsection{Proposal for a Common European Sales Law}

According to Art. 3 CESL, the Common European Sales Law will only be applicable if the parties validly agree to opt into the instrument. ${ }^{47}$ In practical terms, the parties will have to opt into the instrument requiring positive action; otherwise it will not apply to their transactions. According to recital 24, the Commission strongly encourages the parties to opt for the whole document when choosing for the European instrument. There is also a possibility to rely on the CESL outside of its formal scope if the provisions are put into standard contract terms if they are compatible with the national provisions. ${ }^{4}{ }^{7}$ The European Parliament supports the optional nature of the instrument. ${ }^{49}$ This type of legislation is not completely new either since the Societas Europea Regulation already provides for a $28^{\text {th }}$ company law regime..$^{\circ}$ Further options were also given in the European Economic Interest

\footnotetext{
43 See also: Magnus 2012, p.228.

49 European Parliament resolution of 25 November 2009 on the Communication from the Commission to the European Parliament and the Council - An area of freedom, security and justice serving the citizen -Stockholm programme, 25 November 2009, P7_TA(2009)009o, at 99; JURI 2013, p.8. 
Grouping ${ }^{51}$, the European Cooperative Society ${ }^{52}$ and the Community Trademark system..$^{53}$

Yet this form might constitute a 'heavier psychological barrier' compared to the optout system of the CISG. ${ }^{54}$ Despite this disadvantage, the choice for an optional instrument has also been guided by political considerations. If the Commission had chosen for a mandatory instrument this would have put the Member States in a dilemma between their legal obligation towards a treaty under public international law and their legal obligation to abide by the Treaty on the Functioning of the European Union (TFEU) dictating that secondary legislation be binding upon Member States. ${ }^{55}$ Additionally, the Commission became aware that traditional harmonisation would not be possible in that field. ${ }^{6}$ Ultimately, the obligations of the Member States towards the CISG would have rendered it impossible for the CESL to be modelled as an opt-out system. ${ }^{57}$

\subsection{The end-users: businesses}

Legal instruments in the field of international trade law depend on their attractiveness for businesses because they are optional instruments. In other words, the companies carrying out trade abroad must enter them voluntarily and they will only opt into the instruments if there are enough incentives to do $50 .{ }^{58}$ 'Economic reasoning begins with the proposition that individuals are in a better position to understand what is in their own best interested than courts or governments'.59 This is because parties will only agree to a commercial transaction if they are both left better off. For an internal market to be efficient, it must make those exchanges easier, which in turn will lead to economic growth. ${ }^{60}$ This section aims at understanding the state of mind of businesses by explaining their behaviour in general. The second part points out the gaps between the data collected for the European proposal and the reality and the last part places the findings in the perspective of the law.

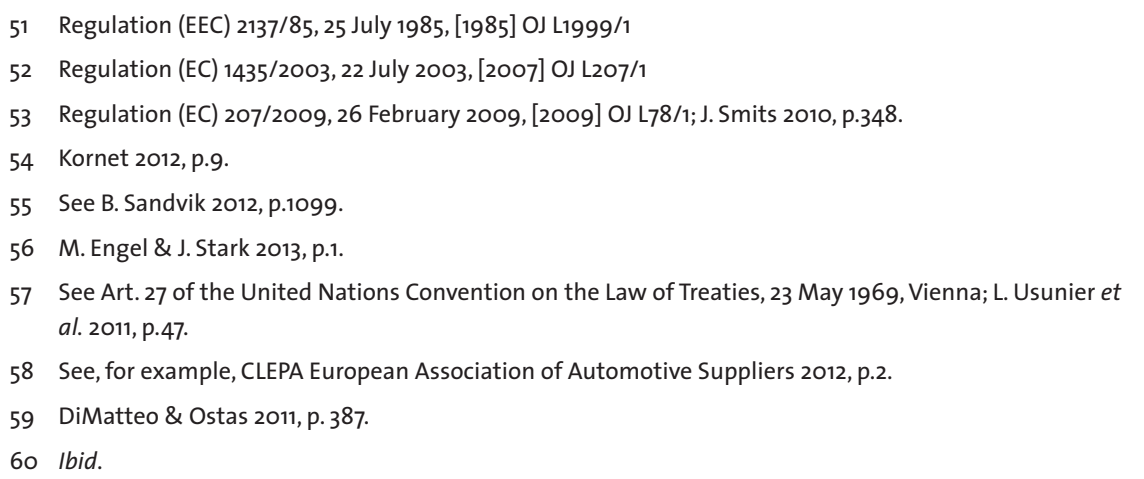




\subsubsection{Business behaviour}

Businesses have been grouped into different categories for legislative purposes. The categories depend on the jurisdiction but most often undertakings are classified based on their size and related factors into micro, small, medium and large companies. ${ }^{61}$ Since CESL is currently confined to the commercial transactions where at least one of the parties is a small or medium enterprise, this section focuses on this category and limits its study to the European businesses. ${ }^{62}$

In Europe, a Commission recommendation gives the definition of SMEs in order to distinguish them from larger companies based on the amount of employees, the annual turnover and the balance sheet. ${ }^{63}$ This characterisation has been placed back on the agenda with the CESL proposal relying on the same definition. ${ }^{64}$ The small or medium-sized enterprises represent now $99.9 \%$ of the European businesses. Half of them count only one employee and SMEs do not count more than six employees in average. Moreover, they do not generally enjoy the privilege of having a legal department within the company. The European Association of Craft, Small and Medium-sized Enterprises (UEPMAE) stresses that this business structure is not suitable for conducting international trade directly. ${ }^{65}$ This is reflected in the amount of SMEs trading with companies situated in another Member State: three EU companies out of four do not conduct cross-border trade. ${ }^{66}$

Due to limited resources, businesses begin by determining their objectives. ${ }^{67}$ This decision is taken by a variety of individuals, whose views might diverge. Past and current events play a role in shaping the aspiration of the firms but it is limited to what is deemed 'realistically achievable'. 68 The decision to carry out business abroad is one of the goals to be decided upon within the company since this is part of its 'strategy'. ${ }^{69}$ The tendency to think in terms of international strategies and solutions seem however more common amongst large firms..$^{70}$ Generally, when businesses have the impression that they are

\footnotetext{
61 See, for example, Service Public Fédéral Belge 2010; Ministère de l'Economie et des Finances 2012; IPYME.

62 JURI 2013, p.8.

63 Commission Recommendation 2003/361, [2003] OJ L 124/36.

64 Art. 7(2) CESL.

65 UEAPME 2012a, pp.1-2.

66 Reding 2012, p.2.

67 G. Low 2012, p.526.

68 G. Low 2012, p.527.

69 G. Low 2012, p.531.

70 G. Low 2012, p.535-536.
} 
not reaching their 'aspiration level', they search for a 'quick fix' solution and only in rare exceptions will the firms go beyond what is strictly necessary. ${ }^{71}$

Which process do they go through when they do trade abroad? SMEs willing to trade abroad first carry out an in-depth analysis of the market to decide whether it is economically sound to take that step. Of course, it includes more factors than the legal consequences this change would trigger. When the analysis is promising, they start with one Member State, usually across the border. If this attempt succeeds, SMEs are likely to consider another Member State or several ones but overall they concentrate on a few Member States only. ${ }^{72}$ In other words, the focus for smaller firms when they expand further than their domestic state is likely to be limited to a few states rather than a will to spread all over Europe.73

\subsubsection{Data vs. reality}

A survey by Clifford Chance LLP showed that $83 \%$ of businesses across Europe viewed favourably or very favourably the concept of a harmonised European contract law.74 Unfortunately, the assumption that differences in the contracting legal systems of the Union discourage cross-border trade is not always supported by reliable empirical evidence..$^{75}$

The Commission has attempted to gather statistical data evaluating to which extent legal barriers prevent businesses from trading abroad. ${ }^{6}$ However, criticism exists towards the Eurobarometer surveys carried out, on the grounds of the inadequate sample of interviewees and the framing of the questions intended to obtain specific answers. For example, this survey was limited to companies already trading in a cross-border failing to include those not yet abroad. ${ }^{77}$ An example of the subjectivity related to the interpretation of data can also be found. In its proposal, the Commission states from the start that differences in contract law deter traders from conducting business abroad..$^{8}$ The survey instead reveals contradictory numbers with only $3 \%$ of businesses being always deterred to trade cross-

\footnotetext{
71 G. Low 2012, p.528-529.

72 UEAPME 2012a, p.1.

73 Low 2012, p.531.

74 Popham 2005. See S. James 2012, p.1; Compare S. Vogenauer \& S. Weatherill 2006, p.117, p.138.

75 Engel \& Stark 2013, p.1.

76 Flash Eurobarometer 2011a; Flash Eurobarometer $2011 b$.

77 UEAPME 2012a, p.4-5.

78 CESL, p.2 et seq.
} 
border while $12 \%$ often refrain from doing so. ${ }^{79}$

Issues of survey validity are not limited to the Eurobarometer survey. In a recent survey on the implications for choice of forum and choice of contract law in the business sector ${ }^{80}$, the Oxford Institute for European and Comparative Law and the Centre for Socio-legalStudies interviewed $95 \%$ of large enterprises and $90 \%$ of the interviewees had received a legal training. Yet, "[a]s is well-known from sociological research of the law, the law of contract is not that important for running a business, unless persons who are legally trained are interviewed'.81 Overall, contract law only comes into play when there is a conflict between the two contracting parties. In other words, the law will affect individuals in very rare instances even though the surveys might reflect the contrary.

Furthermore, under the heading 'no need for a Common European Sales Law in the B2B sector' the International Chamber of Commerce (ICC) explains that no evidence was brought by their members that 'SMEs are being hindered significantly in their cross-border business activities or that firms are deterred from engaging in cross-border trade altogether as a result of the different legal systems that exist in Europe'. To the contrary, they believe that all European systems accept the freedom of contract, which in turn allows for businesses to contract freely via individually negotiated contract terms or standard terms. They wish to explain the answers to the surveys as follows: it would be easier if there was only one law but this does not imply that they do not conduct cross-border trade because there is more than one law. ${ }^{82}$

\subsubsection{Law and businesses}

'As one of the main beneficiaries of this reform, it is crucial to understand whether and how the firm perceives of legal diversity as a problem and an optional instrument as a solution in cross-border trade. ${ }^{83}$ It is true that the negotiations over the applicable law might deter businesses from entering into cross-border transactions. ${ }^{84}$ This is because of their lack of information concerning the other domestic law. ${ }^{85}$ In that respect, legal practitioners will play

\footnotetext{
79 Flash Eurobarometer 2011a.

8o Oxford Institute of European and Comparative Law and the Oxford Centre for Socio-Legal-Studies, 'Civil Justice Systems in Europe: final results'.

81 Rutgers 2011, p.8.

82 ICC Commission on Commercial Law and Practice 2012, p.1-2.

83 Low 2012, p.522.

84 CLEPA 2012, p.1.

85 Webster 22-10-2012, p.1.
} 
a key role in determining whether the businesses will opt into the CESL. ${ }^{86}$ It is difficult to understand the law of a foreign legal system even as a lawyer and time constraints during the negotiations create an obstacle for consulting with a foreign lawyer. ${ }^{87}$ In addition, the reliance on legal advice leads to additional costs. Those costs are two-fold since they imply both the prior enquiries regarding the various laws that could be applicable and the costs of legal disputes. ${ }^{88}$ This is especially relevant for SMEs because they 'cannot afford to spend much money on legal fees nor have contracts drafted in much detail.'89

The problem of legal diversity grows proportional to the amount of Member States a company is trading with..$^{\circ 0}$ The risk of adding a new commercial legal system is to increase legal uncertainty rather than decreasing it. Consequently, it would render legal advice even more necessary, leading to more costs..$^{91}$ In fact, despite the optional nature of the instrument, SMEs will still analyse the various national laws in order to compare which one is more profitable. The wider variety of choices might inflate the costs of legal advice accordingly. ${ }^{22}$ The legal expenses could however be diminished to some extent if enterprises associations know about the new system of law instead of limiting the training to legal practitioners. ${ }^{93}$ Unfortunately, legal professionals will remain essential whereas a European model contract could be more user-friendly. ${ }^{94}$ Furthermore, the UEAPME specifies that the focus for SMEs lies on a 'concrete foreign market' instead of wanting to cover all EU Member States in general. For this reason, the costs of national legislation information gathering should not be exaggerated. ${ }^{95}$ Finally, default rules, or facilitative rules, only allow in practice for freedom of choice of the bigger companies whereas SMEs have to agree with the terms and consequently spend money on gathering knowledge on this imposed law. ${ }^{96}$

\footnotetext{
86 Reding 17-12-2012, p.2; See J. Smits 2012, p.12.

87 Whited 2012, p.172.

88 See also: Magnus 2003, p.3.

89 Knieper 2006, p.478.

90 Low 2012, p.535. 
The role played by the contract is merely to prevent 'surprises' from occurring, it is not essential to the functioning of trade itself. 97 To quote the pragmatic Anglo-Saxon opinion of the Law Commissions of Scotland and England and Wales '[f]or most businesses, contract law is rarely a high priority. The overwhelming majority of contracts simply work. Even when problems arise, most are resolved without recourse to law or lawyers.' ${ }^{8} 8$ This statement is supported by studies revealing that in some instances traders exclude the law in their transactions and social norms may simply prevail in other cases. In other words, the law becomes mere decorum if the parties do not rely on it even for remedies and other solutions are found. ${ }^{99}$ The lack of interest in contract law is probably due to the fact that most contracts are now standardised; therefore only mandatory rules pose a significant obstacle. ${ }^{100}$

It is undeniable that a common European law will make trade easier but the degree of improvement is debatable. ${ }^{101}$ Therefore businesses will have to calculate the 'efficiency and distributive effects of CESL' to determine the costs of implementing the instrument compared to the benefits it would bring. ${ }^{102}$ In the end, those implementation costs might be lower than the benefits encouraging the company to make use of it. ${ }^{103}$ Yet an increase of costs will be caused by the need for companies to learn about a new set of laws and to include it in the negotiations even if they do not choose it. ${ }^{104}$

If the company is already trading abroad, the study of the new instrument will amount to the same costs as those of looking to invest in a new state except that in this case it has only not to be done once. For companies that would like to start trading abroad, they will be able to spend money investigating one legal system instead of 28 in order to cover the same territory. ${ }^{105}$ This is however based on the assumption that businesses intend on trading on a European-wide scale and that legal diversity exists despite the CISG. This brings this section to a final remark. When it comes to international trade law, economics experts must also be included in the discussion instead of leaving it to the lawyers and legal academics to

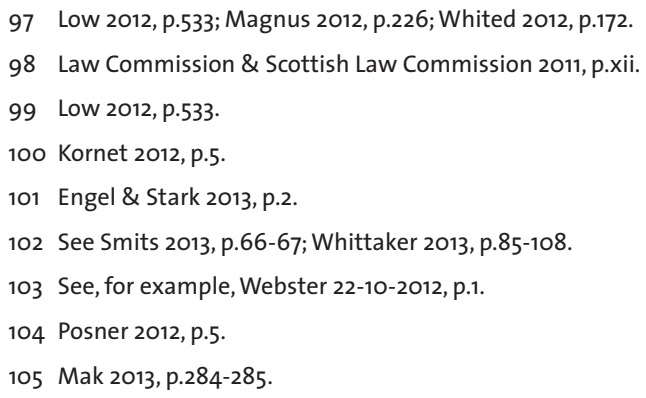


guess the businesses' needs. ${ }^{106}$ Comparative legal research alone is insufficient to determine whether harmonisation is necessary and if it is, which rules to include. ${ }^{107}$ Furthermore, economic models trying to anticipate the reaction of businesses are themselves based on assumptions which would need to be studied by sociologists for example. ${ }^{108}$

\section{The success of the Convention on the International Sale of Goods}

The CISG Advisory Council qualifies the Convention as highly successful. 109 This section evaluates the achievements of the CISG relying on its impact on the contracting states and the businesses as well as its significance in politics and legal academia. Its accomplishment constitutes another aspect to consider in determining the extent to which the Convention is an obstacle to the Commission proposal. The European legislators may also draw inspiration from the keys and pitfalls of success.

\subsection{Ratification by the states}

From a political point of view, the CISG was faced which much less opposition from the nationalists than the CESL is. It gathered as many as 18 ratifications less than ten years after its adoption. In 2013, the CISG now counts 79 contracting states. From a European perspective, all 28 Member States have ratified the CISG besides the United Kingdom, Malta, Ireland and Portugal. ${ }^{10}$ If the broader EEA scope of CESL is taken into consideration, Liechtenstein must also be added to the list."' Moreover, Denmark, Finland and Sweden made use of Art. $92 \mathrm{CISG}$ to exclude part II on formation. ${ }^{122}$ However, Portugal is likely to accede soon to the Convention. ${ }^{13}$ In practice, about $80 \%$ of international sale transactions

\footnotetext{
106 For an example of cooperation, see Ben-Shahar 2013, p.3-5.

107 Herings \& Kanning 2008, p.256.

108 See, for example, Herings \& Kanning 2008, p.258.

109 CISG-AC Declaration No. 1 at 1.

110 UNCITRAL - CISG Status.

111 Sandvik 2012, p.1099.

112 Magnus 2003, p.2.

113 Schwenzer and Hachem 2009, p. 457.
} 
can theoretically be covered by the CISG. ${ }^{114}$ The contracting states include the top 10 exporters and importers except for the United Kingdom. ${ }^{15}$ The latter has not ratified the CISG because its ratification is not a priority for the government and the public consultations have shown a very low response rate due to 'the technical nature of the subject and its relatively uncontroversial nature'.16

Dr. Knieper, a commercial law professor and scholar, has proposed several criteria to determine whether a country would decide to accede to the CISG or not. He argues that compatibility with the existing legal system plays a role in deciding to apply this new set of rules. Further, stability seems to be a key factor since businesses appreciate to be able to rely on fixed and long term laws diminishing in turn the legal costs. Flexibility also contributes to the decision by allowing contracting states to limit the application of the convention, such as the leeway offered under Artt. 92-96 CISG. ${ }^{17}$ On the other hand, although restrictions may be profitable for a contracting state, it impedes on uniformity and increase transactions costs for end-users at the global level. Overall, political ideas or legal culture do not seem to influence this decision as such. In short, it appears that '[...] the CISG is more neglected than resisted'.118

\subsection{Use by businesses}

The views evaluating the use of the CISG by the businesses differ. On the one hand, it is argued that the CISG is only opted out by parties assisted by legal advisers. ${ }^{119}$ The 1993 Report of the Scottish Law Commission on the Formation of Contracts presented a position in favour of the CISG to the government and mentioned that 'these rules now apply very widely in international trade'.120 Recent data also support the idea that large businesses have stopped derogating from the CISG automatically. ${ }^{121}$ On the other hand, authors put forward the low rate of use of the Convention as a factor to take into account for the CESL. ${ }^{122}$ The Law Society of England and Wales argue that the 'uniform codes' available

\footnotetext{
114 A/CN.9/758, p.3; Magnus 2010, p.71.

115 A/CN.9/758, p.3.

116 Moss 2006, p.1.

117 Knieper 2006, p.478.

118 Knieper 2006, p.479-48o.

119 Hesselink 2012, p.352.

120 Scottish Law Commission 1993, p.4.

121 Hondius 2007, p.113.

122 Sciaudone 2012, p.10; Allen \& Overy 2013, p.3.
} 
such as the CISG, the UNIDROIT Principles of International Commercial Contracts (UPICC) or the Uniform Commercial Code (UCC) are 'rarely' used in contracts because national legal systems are preferred. ${ }^{123}$ The literature also supports that the business community does not necessarily find uniform international instruments desirable. ${ }^{24}$

According to the Commission itself, 'only a relatively small number of traders use the Vienna Convention.'25 This comment is based on a Eurobarometer survey asking 'which contract law most often governs your business to business cross-border transactions' to which $9 \%$ answered 'contract laws not related to any particular country, e.g. international conventions or UNIDROIT principles'.126 The report was however limited to European businesses, the majority of which were SMEs. Moreover, in the analytical report on European Contract law, it has been shown that the answers to survey represent the impressions of companies rather than what law applies to their contracts in reality. ${ }^{127}$ In other words, it could well be that the companies are actually relying on the CISG whereas they believe it is national law, since it has been recognised as part of the national system due to its automatic application.

In general, the opt-out rate seems to vary depending on the jurisdiction. In fact, even though there is no general attitude towards opting out, this is the case in some jurisdictions. ${ }^{128}$ Moreover, instead of a case-by-case approach, it appears that the decision to opt-out is more of a general policy decision. Reasons for opting out of the CISG are the lack of knowledge with regard to the Convention, the 'significant learning costs', the bargaining strength, the content and the lack of a court of last instance at the international level. ${ }^{129}$

\footnotetext{
123 Law Society of England and Wales 2012, p.12.

124 Hondius 2007, p.111; Kornet 2012, p.8.

125 CESL, p. 5.

126 Law Commission \& Scottish Law Commission 2011, p.101.

127 European Commission 2011, p.7.

128 See inter alia Kornet 2012, p.8; Koehler \& G. Yujun 2008, p. 45-6o;

129 Kornet 2012, p.8-9.
} 


\subsection{Evaluating the success of the CISG}

Despite being referred to as the 'most important legal basis of today's globalised trade'130, 'a relative optimum'131, 'by far the most successful international private law convention worldwide'132 or '[...] the single most successful among the few success stories in our field'133, an unanimous academic stand on the success of the CISG does not exist. However, the majority puts forward the following arguments to support its victory since its success among the business community must not be confused with its political success.

First, the Convention is not only used by private parties but it also had impact on other (model) laws. ${ }^{134}$ Certain similarities can be pointed out between the Uniform Act on General Commercial Law drafted by the Organization for the Harmonisation of Business Law in Africa (OHADA) and the CISG. According to some, the UPICC, the PECL, the DCFR and the proposal for a CESL and the EU Consumer Sales Directive are based on the UNICTRAL instrument. ${ }^{135}$ At a national level, the sales laws of Scandinavia, the Netherlands, Germany, China, Japan, other Asian countries, many Eastern European countries and a few Baltic countries are said to follow the CISG approach. ${ }^{136}$ This occurred mainly in countries where the legal system was modified in the 1990's. Second, a significant amount of court decisions rely on the CISG, including arbitration cases. The amount of cases published in English is estimated in thousands. ${ }^{137}$ Third, the scholars deal with the topic abundantly in literature. Lastly, lawyers and businessmen have by now become acquainted with the UN instrument. ${ }^{138}$ Its political popularity is however diminished by the non-ratifications and the reservations made to the Convention. ${ }^{139}$

\footnotetext{
130 Magnus 2010, p.71.

131 Magnus 2010, p.95.

132 Schwenzer 2012, p.458. See also: Schwenzer \& Hachem 2009, p. 140.

133 Kronke 2006, p.451.

$134 \mathrm{~A} / \mathrm{CN} .9 / 758$, p.3

135 See Magnus 2003, p.4; Magnus 2010, p.71-72; Kronke 2006, p.456.

136 Schlechtriem 2005, p. 30-31; A/CN.9/758, p.3; See also: Magnus 2003, p.4; Magnus 2010, p.71; Hondius 2007, p.113.

137 Magnus 2010, p.71.

138 Lando 2005, p.380-381.

139 Magnus 2003, p.2.
} 


\section{Eurocentrism disturbing the harmony of the legal environment}

CESL might lead to a more complex legal system and more bureaucracy. ${ }^{140}$ The move from an international instrument to a regional instrument might be inconsistent with the Union strategy to reinforce the position of European companies, especially SME, at the international level. ${ }^{141}$ After all, is regional harmonisation desirable next to global harmonisation? ${ }^{12}$

\subsection{The necessity for a European instrument}

The Commission points out that all Member States have not ratified the CISG. It criticises its limits failing to cover contractual issues 'comprehensively'. ${ }^{143}$ Further it argues that the Court of Justice of the European Union (CJEU) could provide for a uniform interpretation compared to the absence of mechanism for uniform interpretation under the CISG. Moreover, the CISG provides a restricted amount of authoritative languages, namely English, French, Spanish, Russian, Arabic and Chinese. ${ }^{144}$ However, the variety of language might be a weakness rather than an asset in European settings due to the CIFLIT Ruling. ${ }^{145}$ The Court ruled that last instance courts are exempted from the obligation to refer a preliminary question if inter alia the matter is equally obvious to all Member States according all language versions. This leads to more costs in the proceedings as well as to the duty to seek legal advice concerning the different versions. ${ }^{146}$

'Why put a second level on cross-border contracting in a related matter when the parties to a $B 2 B$ transaction already have an instrument at their disposal? Why artificially separate international and EU cross-border trade, which will make transactions more complex, instead of giving the parties more legal certainty as

\footnotetext{
140 CLEPA 2012, p.2.

141 Kornet 2012, p.11; See COM (2011) 702 final.

142 See also: Schwenzer 2012, p. 459.

143 See Section II. 2. (supra).

144 CESL, p.5; Law Commission \& Scottish Law Commission 2011, p.99; Kornet 2012, p.10.

145 Case 283/81 Srl CILFIT and Lanificio di Gavardo SpA v Ministry of Health [1982] ECR 3429; Law Commission \& Scottish Law Commission 2011, p.99.

146 Law Commission \& Scottish Law Commission 2011, p.101.
} 
promised by the Commission? Therefore, it seems highly doubtful whether under the 'necessity'-test the EU has jurisdiction at all to regulate cross-border B2B sales (and related service) transactions by adopting the CESL instrument'.147

The existence of the CISG makes the need for uniformity less urgent although it is worth considering a European initiative. ${ }^{14^{8}}$ Currently, cross-border commercial contracts within the European Union are subject to the Rome I Regulation. According to this Regulation, any legal system may be chosen to apply to the contract including a non-European legal system. ${ }^{149}$ On top of the existing CISG and the various national systems, "CESL "simply" adds one more choice to the many that businesses already have'.150 The ICC also believes that it will be difficult to be more beneficial than the CISG and it will result into a lesser understanding of the legal situation. ${ }^{151}$ Those assets are however necessary because businesses will only opt into the CESL if it brings an 'added value' to the default contract law of 24 Member States. ${ }^{152}$ If the CESL proposal is adopted as it stands now, the legal environment will look as follows. Companies will need to rely on national law for domestic transactions, they will have the option to choose for the CESL for European transactions and for transactions involving businesses outside of the EU the already established CISG will apply. ${ }^{153}$

Considering the preference of companies for lesser costs, be it time or money, one may conclude that this will make the legal environment even more complex and will increase the costs for the companies. However, each type of company may have different aspirations and developed its structure in accordance to them. ${ }^{154}$ In that case, companies thinking locally with a few employees only face national law, those with a European ambition can apply the CESL to their cross-border trade and for the most daring ones the CISG remains available for international trade, including most of the trade conducted within the European Union. In short, it may be that each layer will correspond to a type of likely minded company.

147 Mickitz \& Reich 2012, p.10; See also: Hondius 2007, p.105; ICC Commission on Commercial Law and Practice 2012, p.2;

148 See Usunier et al. 2011, p.21.

149 Law Commission \& Scottish Law Commission 2011, p.xi.

150 Kornet 2012, p.7; See also: Usunier et al 2011b, p.21.

151 ICC Commission on Commercial Law and Practice 2012, p.2

152 Kornet 2012, p.2-3, p.13, p.18; Bull 2011, p.651; Webster 22-10-2012, p.2.

153 See also: Hondius 2011, p.713.

154 See also: Low 2012, p.531; Reding 6-3-2012. 


\subsection{Regional harmonisation}

\subsubsection{Regional vs. global harmonisation}

The CISG Advisory Council points out that CESL 'would [...] trench upon' the CISG because of its application to commercial transaction when one party is a small or medium-sized enterpriseand its entire application to commercial transactions if this is decided by the Member States. ${ }^{155}$ In its recent proposal to further the efforts of the CISG which will be presented in the next section, Switzerland commented that regional harmonisation of laws does not benefit international trade but renders it even more difficult. ${ }^{156}$ The Council also expresses its concerns about the increasing complexity of the pre-contractual phase if the contracting parties were to choose between a global sales law and a regional sales law on top of their national laws. It further argues that 'a key attribute of uniformity and harmonisation is also simplicity', which is here threatened by regional endeavours. ${ }^{157}$

First, the plurality of legal instruments will result into fragmentation contrary to the aim. ${ }^{158}$ Second, regional harmonisation will add another layer to the existing legal systems. Third, those harmonising efforts use a different wording than the CISG.159 Fourth, they might also introduce new legal solutions. All those elements will create a more complicated legal environment leading to higher costs, which will in turn fail in increasing the amount of cross-border transactions. In addition, the more regional initiatives, the lesser case law dealing with the CISG at the international level, this will affect the development of case law ensuring the predictability of the interpretation of the Convention. ${ }^{160}$ Overall, this will discourage countries from acceding to the Convention. ${ }^{161}$

In short, Switzerland believes that 'regional endeavours to harmonize and unify general contract law cannot meet the needs of international trade.' Likewise, the Council harshly puts in doubt the ability of other attempts to reach solutions as good as those of the CISG. Nevertheless, it recognises the enriching contribution of the regional initiatives including the developments it leads to in the field of comparative law. ${ }^{162}$ Similarly, Switzerland sees

\footnotetext{
155 Art. 7 CESL; Art. 13(b). CESL; CISG AC Declaration No.1, at 3.

156 CISG AC Declaration No.1, at 4.

157 Ibid.

158 lbid.

159 Schwenzer 2012, p.478-479.

$160 \mathrm{~A} / \mathrm{CN} .9 / 758$, p.7.

161 CISG AC Declaration No.1, at 5.

162 CISG AC Declaration No.1, at 4.
} 
an advantage in the work that has already been done at the regional level in order to improve the international level. ${ }^{163}$

\subsubsection{Regional harmonisation in the world}

'Europe is not the only part of the world envisaging a regional harmonisation of sales law'.164 In Africa, OHADA created a Uniform Act on General Commercial law in 1998 and it also published a first draft of Uniform Act on Contract law in collaboration with UNIDROIT. ${ }^{165}$ They have also established a court of last instance to judge on those matters and both case law and legal writings linked to the uniform law are proliferating. ${ }^{166}$ Notably, this uniform law is applicable both for cross-border and domestic sale transactions, as well as being mandatory. ${ }^{167}$ Since 2009, Asian countries are working on Principles of Asian Contract Law. In South America, countries are working since 2009 on the Proyecto sobre Principios Latinoamericanos de Derecho de los Contratos. Convergence of regional law can also be seen in the North American Free Trade Agreement and the Dominican RepublicCentral America Free Trade agreement. ${ }^{168}$ Finally, the Nordic Sales Act of 1905 could also be seen as a regional harmonisation within Europe.

Conclusively, the CESL will not solely be responsible for a fragmentation of international trade law. To the contrary, regional harmonisations may be the stepping-stones in building a more complete and up-to-date international trade law. ${ }^{169}$ This enables states to find a compromise in smaller groups before negotiating uniform rules on a global scale with the additional forty-four countries that joined the United Nations (UN) after 1980. ${ }^{170}$ From a pragmatic point of view, regional harmonisations might also be more feasible and will offer a working legal system in a shorter period of time.

163 A/CN.9/758, p.2.

164 Hondius 2007, p.111.

165 A/CN.9/758, pp.5-6; See Magnus 2012, p.229.

166 Hondius 2007, p.111; OHADA, 'Le portail du droit des affaires en Afrique'.

167 Hondius 2007, p.111.

168 A/CN.9/758, p.6.

169 See also: Hondius 2007, p.111.

170 United Nations, 'Member States of the United Nations'. 


\section{Fruitful cooperation vs. competition}

Referred to as competitors, it is expected that the two legal instruments coexist at first and that consequently the best 'product' on the market will win. ${ }^{171}$ This legal rivalry has already been seen at the national level in documents such as 'England and Wales: the Jurisdiction of Choice' or 'Law-Made in Germany: global, effektiv, kostengünstig'. ${ }^{12}$ Regrettably, this is a very static way to predict the outcome of the tumultuous interaction between the CISG and the CESL. To the contrary, those instruments are the result of a naturally evolving process and they share the same values and purpose. Indeed, the European Union was not the first institution to realise the importance and the possible advantages of harmonisation in the field of international trade law and hopefully, they will not be the last ones either. Rather than enemies, the two instruments can better be compared to siblings. The CISG precedes the CESL from a chronological perspective. And even though there might be some competition, the younger instrument looked up to the older one for inspiration. Reciprocally, the experienced instrument might also have tricks to learn from the more innovative CESL.

\subsection{Aims and values}

On a superficial level, the goals of both instruments can be distinguished. On the one hand, the CISG intends to replace national law in cross-border sales transaction, i.e. it aims at a 'global unification of the substantive law of professional international sales of moveable goods'. On the other hand, the CESL wishes to improve the internal market by offering another contractual legal system. ${ }^{173}$ This reflects the decision for allowing a voluntary choice even though one can sense the hidden agenda. ${ }^{74}$ Furthermore, the CISG does not aim at protecting weaker parties whereas the CESL does..$^{75}$ Nonetheless, the legal shortcomings encountered in case of cross-border trade are not unique to the European Union but can be found on a global scale. ${ }^{176}$

Both instruments want to remove the legal barriers to encourage trade because of the underlying belief that wealthy states and states dependent on each other are less likely to

\footnotetext{
171 See CISG AC Declaration No.1, at 5; Law Commission \& Scottish Law Commission 2011, p.101-102.

172 Smits 2010, p.349.

173 Magnus 2012, p.226.

174 Magnus 2012, p.227.

175 Law Commission \& Scottish Law Commission 2011, p.98.

176 Heidemann 2012, p. 1124.
} 
disturb peace.177 Those barriers can be removed by finding a compromise between the rules and apply them uniformly. In the preamble of the CISG, the states party to the Convention identify the goal of promoting peace among states by developing the international trade based on the principle of equality.178 Furthermore, they indicate that they wish to develop trade by removing the existing legal barriers while having regard for the social, economic and legal diversity in the world.179 Even the substantive provisions concerning interpretation reiterate the aim of harmonisation. Art. 7 (1) of the CISG states that '(i)n the interpretation of this Convention, regard is to be had to its international character and to the need to promote uniformity in its application[...]'.

\subsection{Continuous process}

As early as 1929, UNIDROIT started working on a Uniform Sales Law on the basis of a proposal by the famous Ernst Rabel. ${ }^{180}$ In 1936, a very first draft on which the later CISG would be based was published. ${ }^{181}$ In the early 1960's, an international legal colloquium on the sources of law of international trade brought the topic back on the agenda..$^{182}$ In 1964, the Hague Conference on International Sale of Goods was the first attempt to harmonise the sale of goods at the international level, including the social states. It gave rise to the Uniform Law of the International Sale of Goods (ULIS) and the Uniform Law on the Formation of International Sale of Goods (ULFIS). ${ }^{183}$ Unfortunately, this Conference did not necessarily aim at a political compromise. ${ }^{184}$ Instead, it appears that the northwestern states wished to see their domestic law applied at the international level. ${ }^{185}$ Probably for that reason, less than a third of the participating states ratified the Convention and the low ratification rate affected the future of this 'international' law. Nonetheless, this represented the first 'worldwide' ratifications and remained in force between 1972 and 1990 when most ratifying states gave up those Conventions to replace it by the CISG. Moreover, they were relied upon in the first EU member states in Court for uniformity purposes. ${ }^{186}$

\footnotetext{
177 CISG Preamble; Art. 2 TEU; Recitals CESL.

178 CISG Preamble, Recital 2.

179 CISG Preamble, Recital 3.

180 Lando 2005, p.379; Magnus 2010, p.73.

181 Rabel et al. 1936 \& 1957; See Magnus 2010, p.73.

182 UNCITRAL 1992, p.7; Lando 2005, p.379.

183 UNCITRAL 1992, p.5; Lando 2005, p.379; See Magnus 2003, p.2; See Hondius 2007, p.100-101.

184 UNCITRAL 1992, p.5; Lando 2005, p.379.

185 UNCITRAL 1992, p.5; Hondius 2007, p.101.

186 Lando 2005, p.379; Magnus 2012, p.228.
} 
In addition to the disappointing outcome of the ULIS and ULFIS, it appeared that the several agencies preparing the international trade principles worldwide did not cooperate to a satisfying extent. For further developments, it was therefore proposed to opt for an international agency 'of the highest order' such as the United Nations. ${ }^{187}$ In 1966, UNCITRAL was established for this purpose and its mandate includes the task to 'further the progressive harmonization and unification of the law of international trade by: (c) Preparing or promoting the adoption of new international conventions, model laws and uniform laws [...].' ${ }^{\prime 188}$ Consequently, the UNCITRAL started working on this project aiming at the following goals: clarity, flexibility, modernisation and fairness. ${ }^{189}$

In 1980, the United Nations Convention on Contracts for the International Sale of Goods, most commonly referred to as the CISG, was adopted during a conference in Vienna by the representatives of the contracting states. ${ }^{190}$ It played a major role in furthering the uniformity of global contract rules. ${ }^{191}$ Professor Roland Loewe chaired the drafting process next to commercial law experts..$^{192}$ It is important to note that provisions on the formation of contract and the rights and obligations are very similar to the UCC due to the influence of some American Law professors such as Honnold and Farnsworth. ${ }^{193}$ The former was the Secretary of UNCITRAL during the making of the first draft. The notes of the conferences show the role they both played in the choices made during the Vienna Conference. ${ }^{194}$ The impact of the United States on the CISG may also be explained by the economic interdependence of the contracting states. ${ }^{195}$ Other legal systems such as the French and German legal systems also played a role. ${ }^{196}$

Finally, the work of UNCITRAL is not limited to the CISG but also includes the following conventions: the 1974 Convention on the Limitation Period in the International Sale of Goods, the 1983 Uniform Rules on Contract Clauses for an Agreed Sum Due upon Failure of Performance, 1992 Legal Guide on International Countertrade Transactions, 2005

\footnotetext{
187 UNCITRAL 1992, p.7.

188 General Assembly Resolution 2205 (XXI), at 8; Bonell 2002, p.88.

189 UNCITRAL, p.10.

190 See also: CISG AC Declaration No.1, at 5.

191 Lando 2005, p.379.

192 Kronke 2006, p.452.

193 Pfund 2012, p.562.

194 Magnus 2010, p.79-80.

195 Herings \& Kanning 2008, p.260.

196 Magnus 2010, p.81-87.
} 
Convention on the Use of Electronic Communications in International Contracts. ${ }^{197}$ The other Conventions function in parallel with the CISG but they do not count as many members. ${ }^{198}$ The drafting process was the result of comparative research. ${ }^{199}$

\subsection{Stakeholders}

The Commission has held a public consultation in 2010 on the policy options to further European contract law and the expert group on the Proposal for a Common European Sales Law has met with stakeholders such as the ICC. ${ }^{200}$ Regardless the possible criticisms as to the interpretation of those opinions given by stakeholders, the United Nations can draw on this experience to consult more widely with various stakeholders, including the companies and not only their representatives. Again, if the goal is to fix a problem, it is crucial to understand precisely which issues the businesses are facing.

In order to ensure the best future for European Sales Law, the collection of data on the reliance on the CISG itself may be quite helpful. ${ }^{201}$ Indeed, a conclusive survey indicating how many businesses, classified by size categories, make use of the Convention in each country would be a significant contribution. The questions should not stop at this descriptive aspect but they should also ask for the reasons why businesses do or do not opt out of the Convention.202 Finally, a careful drafting of the questions as well as an unbiased selection of participants is necessary. Admittedly, similar surveys have been carried out but an up-to-date collection of data focusing only on this topic would contribute to predict the future of the CESL and would also improve its chances of success.

\subsection{Content}

The CISG has influenced the drafting of the DCFR and the PECL on which the CESL is based. ${ }^{203}$ Yet, even though the provisions are heavily borrowed from the Convention, the wording differs. Stakeholders such as the UEAPME argue for maintaining the wording of

\footnotetext{
197 A/CN.9/758, p.4.

198 lbid., p.7.

199 Magnus 2010, p.72.

200 (2010) 348 final; Green Paper from the Commission on policy options for progress towards a European Contract Law.

201 CLEPA November 2012, p.1.

202 See Law Commission \& Scottish Law Commission 2011, p.102.

203 See Section IV. 3 (supra)
} 
the CISG when those provisions are the basis for the CESL provision. ${ }^{204}$ They also propose to indicate clearly in the CESL when a provision originates from the CISG for clarity purposes. ${ }^{205}$ The Trans Europe Experts group submitted that the method used in the CISG indicating explicitly that each party must be situated in a different country under Art. 1 should be relied upon in the CESL to reach a clear and concise scope instead of a vague cross-border characterisation. ${ }^{206}$

The structure of the document, its length and the detail of its content makes the CISG user-friendly and it allows for flexibility. ${ }^{207}$ For those reasons, the CESL should take it as a model. ${ }^{208}$ On the other hand, some argue that since the CISG excludes consumers and the CESL aims at protecting consumers in $\mathrm{B}_{2} \mathrm{C}$ transactions, the former cannot be taken as an example for the latter. ${ }^{209}$ Nonetheless, the Directive on Consumer Sales of 1999 already took over provisions from the CISG despite their divergent scopes therefore borrowing can still be envisaged especially in the commercial context. ${ }^{210}$

The most recent CESL also brings three novelties to the old understanding of international trade law: consumer law, standardised contracts and digital transactions. ${ }^{211}$ Indeed, the CESL took into account that the consumer is actually the main actor when it comes to international transactions..$^{212}$ In 1980, it was assumed that the key actors able to buy and sell abroad were (large) firms. Nowadays, the invention of Internet changed the meaning of international trade itself. It further deals with standard contracts in a few instances while this is left unregulated by the CISG. Lastly, the CESL incorporates the fact that contracts are concluded over the Internet and that the good itself might also consist of digital content. ${ }^{213}$ In short, this makes the CESL an instrument more in line with the modern times. ${ }^{214}$

204 See also : Lando 2005, p.381; UEAPME 2012C, p.3; UEAPME 2013, p.5.; See also: Magnus 2003, p.8.

205 UEAPME 2012c, p.3; UEAPME 2013, p.5.

206 Usunier et al. 2011a, p.17.

207 Magnus 2003, p.5; Magnus 2010, p.95; Law Commission \& Scottish Law Commission 2011, p.98.

208 Magnus 2003, p.5.

209 Mickitz \& Reich 2012, p.17.

210 Magnus 2010, pp.71-72.

211 R. Schulze 2012, p.1.

212 Ibid.

213 Schulze 17-12-2012, p.2.

214 Schulze 17-12-2012, p.3. 


\subsection{Negotiations}

The CISG can also give some insights as to the result of the political process. This older international instrument was confronted with the challenge to combine civil law and common law. The working method was based on consensus and took account of the less developed states contrary to the Hague Conventions. ${ }^{215}$

On the one hand, ' $[t]$ he CISG proves that contradictions and differences between legal systems', in particular the gap between common law and civil law [...] can be successfully overcome'. ${ }^{216}$ According to Dr. Lando, a renown international contract law expert, the success and the respect for the CISG stem from the 'careful codification procedures' undertaken. ${ }^{217}$ As a guiding principle, it aimed at finding a compromise between the different legal systems, relying at times on existing laws such as United States, German and French law. ${ }^{218}$ The drafters applied the 'common core' and the 'better rule' principles to decide on the provisions. The former consists of a comparative approach looking for similarities whereas the latter relies on legal or political choices determining which rule has higher value. ${ }^{219}$ When the comparative approach or the best solution approach was unsatisfactory, novel rules have been found.220

On the other hand, the compromise sometimes resulted in an inefficient solution such as illustrated by the conflicting agreement found concerning the writing requirements under Art. 11 and Art. 12 CISG. ${ }^{221}$ The failure to find a political compromise sometimes resulted in gaps in the CISG, such as it was the case with specific performance, and the European initiative should avoid this during the future negotiations. ${ }^{222}$

\subsection{Promotion of the instrument}

Due to its opt-in nature, CESL will depend on its promotion among the stakeholders whereas the CISG is to some extent 'imposed' on uninformed businesses. It must also be kept in mind that the economic crisis might no place the information campaign of

\footnotetext{
215 UNCITRAL 1992, p.10; See Hondius 2007, p.102.

216 Magnus 2010, p.96; See also: Hondius 2007, p.101.

217 Lando 2005, p.384.

218 See Lando 2005, pp.381-382; Magnus 2010, p.74.

219 DiMatteo \& Ostas 2011, p. 375-376.

220 Lando 2005, p.382.

221 DiMatteo \& Ostas 2011, p. 379.

222 See A/CN.9/758, p.6; DiMatteo \& Ostas 2011, p.372-373.
} 
the CESL as a priority. ${ }^{223}$ Up until today, the future optional instrument has already been included in the following policy documents: ${ }^{224}$ the Digital Agenda for Europe ${ }^{225}$, the Single Market Report ${ }^{226}$ and Europe 2020.227 Furthermore, the Commission proposes to support the drafting of standard terms and conditions, the translation of those terms and the training of judges. ${ }^{228}$

Dr. Smits, the director of the Maastricht European Private Law Institute, argues for a more 'innovative' marketing of the CESL. He encourages to think out of the box and not to stop at traditional actors such as the Member States, the European Union and the legal professionals. ${ }^{229}$ According to him, new technologies should be used to show the end-users how the CESL differ from their own system and why this would be in their interest. He gives the example of an evolving website ranking various applicable laws to contracts indicating to consumers and traders which system is best. ${ }^{230}$ This way, the assets and disadvantages of the CESL compared to the CISG could also be shown.

Other possibilities for the promotion of the instrument are commentaries, such as the one published by Professor Schulze ${ }^{231}$ or an advisory board proposed by the Working Document. More importantly, SME organisations can contribute to the promotion by offering trainings and other assistance since the firms are likely to first contact their association. ${ }^{232}$ Ultimately, the instrument itself may in turn offer marketing advantages less obvious in the case of the CISG: a European label would show interest in cross-border commerce. 233

\footnotetext{
223 UEAPME 2012a, p.2.

224 Low 2012, p.523.

$225 \operatorname{COM}(2010) 245$ final, p. 12-13.

226 Monti 2010, p. 93-94.

$227 \operatorname{COM}(2010) 2020$ final, p. 19.

228 CESL, p.11; Reding 17-12-2012, p.3.

229 Smits 2012, p.12.

230 Smits 2012, pp.12-13.

231 Reding 17-12-2012, p.3.

232 UEAPME 2012c, p.2.

233 Webster 22-10-2012, p.1.
} 


\subsection{Uniform interpretation}

The enforcement means to ensure the application of the CESL provisions appears as a factor in advising the clients to rely on the instrument.234 Under the CISG, the judicial protection on which the parties can rely to enforce a contract is left to the national courts subjected to a duty of uniform interpretation. 235 Therefore, an enforcement mechanism exists but in as much as uniform laws are necessary, uniform interpretation is crucial for harmonisation. This reasoning is best illustrated by the following quote: 'the uniform law from the very moment of its coming into operation starts to differ from itself. Every judge in every country is a sovereign interpreter of the text, and the judge became a judge by learning the system of law of his own country'.236 For this purpose, UNCITRAL created a Digest on the CISG as well as CLOUT, a database containing case law based on the texts of UNCITRAL. ${ }^{237}$ The CISG has also installed the CISG Advisory Council for further guidance as to the interpretation and the application of the Convention. The European Law Institute (ELI) suggests the CESL to do the same in order to improve implementation. ${ }^{238}$

Luckily, in the case of a European instrument, the CJEU could step in to give a uniform interpretation throughout the European Union. ${ }^{239}$ However, the backlog of cases at the CJEU pushing back the delay before judgment to more than 16 months in 2010 and longer than two years for the General Court is an issue for businesses that favour efficiency and certainty. ${ }^{240}$ Moreover, national delays must be added to the length of preliminary ruling procedure which reached 13 years in the most extreme case. ${ }^{241}$ However, a database could actually defeat those practical obstacles and it could also influence arbitration courts, which might be preferred by business parties. ${ }^{242}$ In fact, such reporting system has even revealed that differences are not so great in practice in the case of the CISG. ${ }^{243}$

\footnotetext{
234 Ibid., p.2.

235 Art. 7 CISG.

236 UNCITRAL 1992, p.6.

$237 \operatorname{COM}(2011) 635$ final, p.37.

238 European Law Institute 2012, p.36; CISG Advisory Council.

239 Law Commission \& Scottish Law Commission 2011, p.98; Hondius 2007, p.112.

240 Law Commission \& Scottish Law Commission 2011, p.99.

241 Marks \& Spencer Plc v Customs and Excise Commissioners (No.5) [2009] UKHL 8, [2009] 1 All ER 939 ; Law Commission \& Scottish Law Commission 2011, p.99; See Kornet 2012, p.13.

242 Hondius 2007, p.112.

243 Lando 2005, p.386.
} 
In the CESL proposal, final judgments must be reported in a database under Art. 14 CESL. ${ }^{244}$ This database is most likely inspired by the CISG and the UNIDROIT database. The former is managed informally by the Pace Law School Institute of International Commercial Law. ${ }^{245}$ A case-law database open to the public principally to the use of the lawyers will aim at transparency, 'de-facto' convergence of the jurisprudence, i.e. consistency, and indirectly the decrease of the costs for proceedings as well as the length. ${ }^{246}$ Unfortunately, 'the average European enterprise' will most likely not consult this database. ${ }^{247} \mathrm{ELI}$ insists on a database 'easily searchable' and available in various EU languages respecting the authenticity of the judgment. This could be done by the use of a standard form and judicial as well as legal training should include information about this database. ${ }^{248}$

\subsection{New initiatives}

On top of improving the internal market, the CESL has the potential to have an impact of international sales law by encouraging 'updates' of the current Conventions or at least by introducing new practices and doctrine. ${ }^{249}$

In May 2012, Switzerland submitted a proposal on 'possible future work by UNCITRAL in the area of international contract law'.250 Its proposition is two-fold. First, it wants to consider the current and future needs of businesses and evaluate the ability of the CISG and related instruments to address them. Second, it wants to analyse whether further harmonisation could and should be achieved based on the observations in the first step. ${ }^{251}$ It implies in its argumentation that an international convention should include 'the full array of legal issues that arise in a contractual business to business relationship'.252 Switzerland wished to add to the CISG but it also warns that it should not go as far as to regulate domestic contracts. ${ }^{253}$

\footnotetext{
244 Reding 17-12-2012, p.3; JURI February 2013, p.8.

245 Heidemann 2012, p. 1129; Kornet 2012, p.13; Law Society of England and Wales 2012, p.33; See also: UNILEX; CLOUT database; CISG Database Pace University.

246 Reding 17-12-2012, p.3.

247 UEAPME 2012b, p.3.

248 European Law Institute 2012, p.37-38.

249 lbid.

250 A/CN.9/758, p.1.

251 A/CN.9/758, p.2.

252 A/CN.9/758, p.3.

253 A/CN.9/758, p.6-8.
} 
The reasoning of the proposal is as follows. The divergences in national contract laws are an impediment on international trade despite the 'modern means of communication'. It evaluates the CISG as having increased legal certainty for parties involved in international trade but it is not satisfied with the level of completeness of the instrument. Its more detailed reasoning strikingly resembles the one of the Commission. First, various national contract systems lead to higher transaction costs based on surveys ranging from 'ascertaining the content of an applicable contract law, obtaining legal advice, negotiating the applicable law [to] adapting standard terms'. According to Switzerland, trade is at the origin of contract harmonisation. It criticises the gaps left in the CISG forcing recourse to national law. ${ }^{254}$

\section{The future of the international trade instruments}

\subsection{Improvements}

Since the start of the CISG in 1980, the number of global imports and exports appears to have increased by ten.255 The qualities of the law also lie in its possibility to adapt to the needs of the evolving society. International rules on contract law should not '[...] lag sadly behind the on-going rapid growth of the world trade and communication'.256 This section considers the steps that would need to be taken in order to adapt the trade laws to modern developments such as new technologies.

\subsection{The Convention on the International Sale of Goods}

In the future, more states will probably ratify the Convention improving its status as a global law even further. ${ }^{257}$ Yet its content will also play a key role, hence, some authors have already voiced their will for 'general principles of contract law for the world trade' or even a global code relying on the existing uniform laws has been envisaged. ${ }^{25}$ The CISG Advisory Council stresses the need to harmonise the matters not yet covered by the Convention and supports the Swiss proposal. ${ }^{259}$ However, 50 years were necessary between the emergence of the idea

\footnotetext{
254 A/CN.9/758, pp.2-3.

255 lbid., p.2.

256 Lando 2005, p.384; See also: Hondius 2007, p.106.

257 Magnus 2003, p.1.

258 Bonell 2001, p.88; Lando 2005, p.379, p.384;

259 CISG AC Declaration No.1, at 6.
} 
for a global sales law and the adoption of the CISG. ${ }^{260}$ Even though adaptations of a treaty are legally possible, the political reality may constitute an obstacle to such changes.

The CISG is an international agreement concluded between States in written form and governed by international law, i.e. a treaty. ${ }^{261}$ From a legal perspective, two alternatives are available to the parties to the Convention. First, the governments may negotiate a new treaty. The risk is that not all states will agree leading to a lower ratification rate. Consequently, even though the new treaty could state that it supersedes the previous one, a dual treaty system will subsist: on the one hand, the old CISG amongst those parties who have not ratified the new treaty and on the other hand the new CISG for those parties who have given their consent, regardless of whether they were part to the previous treaty. ${ }^{262}$ This new treaty could either cover all the topics included in the existing CISC modifying it to the extent necessary or a supplementary could also be envisaged with only the necessary elements. Second, the parties to the CISG have a right to amend the current. ${ }^{263}$ This can be done by a proposal consequently notified to all contracting states. If a decision is made to start negotiations, amendments can be made but the current contracting states are not obliged to become parties to the amended treaty. ${ }^{264}$

\subsubsection{The Proposal for a Common European Sales Law}

The CESL will not replace the existing acquis since it is limited to cross-border transactions even though it might contribute to its development. In other words, harmonisation as such will have to be pursued from the very beginning if this is the intention of the Commission, the Member States and the European Parliament. ${ }^{265}$ Overall, the European Union method seems easier to modify because it does not follow the international in-or-out approach but rather the majority voting or even the possibility for a delegating act for non-essential elements. This is supported by a previous attempt of the United Nations to modernise their uniform laws via the 2005 Convention on the Use of Electronic Communications in International Contracts, which sadly counts only three ratifications at the moment. ${ }^{266}$

260 Lando 2005, p.385.

261 Art. 2 (1) (a) Vienna Convention on the Law of Treaties

262 See also: Art. 30 Vienna Convention on the Law of Treaties

263 Art. 39 Vienna Convention on the Law of Treaties.

264 Art. 40 Vienna Convention on the Law of Treaties.

265 See CESL, p.11.

266 United Nations Commission on International Trade Law; '2005 - United Nations Convention on the Use of Electronic Communications in International Contracts - Status'. 
In order to modify the current regulation for an optional instrument, the Commission will have to introduce a new legislative proposal to amend the previous instrument. If the proposal is also based on Art. 114 TFEU, the ordinary legislative procedure under 294 TFEU will have to be followed requiring a majority voting. An alternative to this complex political process would be to delegate powers to the Commission in the original regulation. Under Art. 290 TFEU, this would allow the executive power to 'supplement or amend certain nonessential elements of the legislative act' while being subject to prior limitations laid down by the legislator in the regulation and ex post control since the legislative branch may revoke this right. ${ }^{267}$ Yet this will only be effective for minor elements and will most likely not facilitate the modernisation of the instrument by extending the meaning of digital content for example. In this instance, implementing acts defined in Art. 291 TFEU may not be used since they require the implementation of legally binding acts. Even though a regulation is a legally binding act under Art. 288 TFEU, it is directly applicable and does not necessitate implementation. ${ }^{268}$

The pitfall of adopting a uniform trade law in the form of a treaty is the right to make reservations. This occurs when states declare unilaterally that they wish to exclude provisions from the treaty, leading to a limited application of the agreement since those provisions will not have binding effects upon them. ${ }^{269}$ It is however possible to prohibit reservations in the treaties but this is likely to result in fewer signatories because it removes the margin for compromise. In addition, the treaty itself may allow for accession to parts of the treaty only such as it is the case with the Convention. ${ }^{270}$ However, an optional instrument containing both default and mandatory rules open the door for individuals' reservations, distorting uniformity as well. The advantage of the treaty form is that once the country has given its consent, it is binding upon the entire territory whereas an optional instrument might affect only one individual in the whole territory. ${ }^{271}$

\subsection{The legal and political consequences of a choice between the two instruments}

The scholars opposing the adoption of CESL defend that the adoption of the instrument itself will defeat it when CESL fails to be opted in. ${ }^{272}$

\footnotetext{
267 Craig \& de Búrca 2011, p.134-138.

268 See Nigel Foster, Directions, (Oxford University Press, 2010), p.104.

269 Art. 2 (1) (d) Vienna Convention on the Law of Treaties.

270 Art. 17 Vienna Convention on the Law of Treaties; Art. 92 CISG.

271 Art. 29 Vienna Convention on the Law of Treaties; Art.1 (a) CISG.

272 Hondius 2013, p.3.
} 


\subsubsection{A CESL victory}

The Member States could argue that their legal systems are so 'close' to each other and they can opt out of the CISG together on the basis of Art. 94 CISG. ${ }^{273}$ However, this comprises several pitfalls. First, the reason for harmonising the laws via CESL is that those laws are not so similar. Second, if the Member States were to argue that the new law brought by the CESL is the one they have in common, it will be difficult since the CESL would not be the only regime applicable. Norway, Iceland, Sweden, Finland and Denmark have already made a reservation under Art. 94 CISG. ${ }^{274}$

Under Art. $90 \mathrm{CISG}$, the Convention will not prevail over another subsequent international agreement dealing with the same subject matter, 'provided that the parties have their places of business in States parties to such agreement'. 275 Yet there is an agreement amongst academics that EU secondary legislation does not qualify as 'an international agreement', not so much because of its legal nature but rather because of the enacting party. ${ }^{276}$ Indeed, the European Union if considered as a supranational organisation would be enacting legislation in that field, and it is not a party to the CISG. The situation is however slightly different for those Member States joining after accession to the CISG, in which case Art. 351 TFEU mandates that the Treaty should not take precedence even though the new Member States are then under the obligation to interpret the CISG in a way compatible with the European Treaties. ${ }^{277}$

\subsubsection{A CISG victory}

In case the four Member States that are not currently contracting parties to the CISG decide to accede to the Convention, it will become very difficult for the Commission to show the need for harmonisation. Yet the Commission could also encourage the ratification of the CISG as an alternative way to harmonise the laws of the Member States instead of the costly CESL. ${ }^{278}$

According to the ICC, from a business perspective, the ratification of the CISG would bring more benefits. 'Standard contracts and the application of the CISG play an important role in the largely smooth operation of cross-border contracts between businesses. In

\footnotetext{
273 See Magnus 2003, p.7.

274 CISG-AC Declaration No. 1, at. 2.; Magnus 2003, p.2.

275 Sandvik 2012, p.1110.

276 Sandvik 2012, p.1111.

277 Sandvik 2012, p.1116.

278 Magnus 2003, p.7.
} 
this respect, EU-wide ratification of the CISG would create further benefits'. ${ }^{279}$ Based on the decrease of transactions costs it could lead to, Magnus advocated for an 'unreserved ratification' by all Member States. ${ }^{280}$ It also argued that this would be more proportionate than the introduction of a new legal instrument. ${ }^{281}$

\subsection{Complementarity}

In combining their strengths, both sets of laws may create a coherent complement framework. In the past, the CISG has already faced UPICC as an alleged competitor. Yet the private law professor Dr. Kronke considers their complementarity and denies them being competitors. He sees a 'fruitful coexistence' and even the possibility for improving the CISG with the help of the later via courts, legislators and parties since the UPICC is more flexible than the Convention. ${ }^{282}$ Moreover, it is substantially complementary since it deals with topics not covered by the CISG, probably due to political reasons. ${ }^{283}$

It has also been argued that the European Consumer Sales Directive and the CISG were similar and complementary. ${ }^{284}$ Interestingly, a previous draft of the Directive had already attempted to include the small businesses, by including them in the definition of consumer. In practice, this would have led to an overlap between the two instruments since the same transaction could have fallen under the definition of commercial transaction under the CISG and of consumer transaction under the Directive. For this reason, inclusion of small businesses as consumers would not have been possible in the context of mandatory rules rather than an optional instrument. ${ }^{285}$

Several authors argue for an instrument complementing the CISG instead of replacing it, i.e. by limiting it to consumers. ${ }^{286}$ After all, the European Union is more experienced in the field of consumer law. ${ }^{287}$ This way, CESL would fit within the exception of Art. 2(a) of the CISG. ${ }^{288}$ However, this argument is not entirely convincing. Curiously, despite respective

279 ICC Commission on Commercial Law and Practice 2012, p.3.

280 Magnus 2003, p.3.

281 Kornet 2012, p.11.

282 Kronke 2006, p.458.

283 Kronke 2006, p.459.

284 Directive 99/44/EC, 25 May 1999, [1999] OJ L171.

285 Hondius 2007, p.103.

286 Heidemann 2012, p. 1138; See Bull 2011, p.650.

287 Usunier et al. 2011a, p.21.

288 Heidemann 2012, p. 1131. 
scopes limited to consumer or commercial transactions, some conflicts may also occur. ${ }^{289}$ This is caused by the fact that the CISG will still apply to a consumer transaction if the seller did not know or could not have known that it was not a commercial transaction. In addition, the CISG opts for a narrow interpretation of the term 'consumer' whereas previous EU law such as the Consumer Directive prefers a broader interpretation. ${ }^{290}$ Finally, this complementarity is only necessary in practice for those involved in transactions within the European Union and with third countries. For those companies with European ambitions only, expanding the scope to all B2B transactions regardless of the size of the companies is advocated. ${ }^{291}$

\section{Conclusion}

The interaction between the two international trade instruments should be seen as a fruitful cooperation in the long term instead of a competition. They share the same values and the CESL is rather the result of a long process that had already started in the 1920's. On the one hand, the European instrument draws inspiration from the CISG such as its content and the tools to promote uniform interpretation. The Convention also allows anticipating the problems that will arise during the European negotiations. On the other hand, the CISG can learn from the CESL's decision to include stakeholders and from the new meaning it gave to international trade. Swiss proposal for furthering the efforts of the international Convention proves that the Commission's plans have already had an impact.

Admittedly, the limited commercial scope of the proposal for a Common European Sales Law overlaps with the existing Convention on the International Sale of Goods. This may give rise to conflicts since the Convention applies as the default regime for businesses situated in all Member States whereas firms in Malta, Portugal, Ireland and the United Kingdom must opt into the Convention. As an addition however, the European proposal includes several aspects of contract law not dealt with under the CISG. In practice, European businesses will have to opt out of the Convention and opt into the CESL which makes the success of the European instrument heavily dependent on its attraction to businesses. By focusing on the nature of small and medium-sized enterprises, the CESL meets the needs of the greater amount of businesses. However, this structure itself is not the best fit for

289 Hondius 2007, p.112; Sandvik 2012, p.1097-1098.

290 Sandvik 2012, p. 1098.

291 See UEAPME 2012b, p.3; UEAPME 2013, p.8; Council of Bars and Law Societies of Europe 2012., p.4. 
international trade and SMEs rarely display 'pan-European' aspirations. Moreover, the data supporting the need for a European instrument appears not to be entirely reliable. For this reason, a better collaboration between the various fields involved will improve the chances of success of the CESL by defining the problem accurately. Indeed, the importance of contract law for the functioning of companies should not be overestimated either.

The CISG has gathered an impressive amount of ratifications and it influenced development of both national and international laws. Yet the reliance of businesses on the instrument shows a mitigated success and additional data may be required to understand the situation in order to apply it to the case of the CESL. If the businesses prefer avoiding the CISG, this can be linked to objective opposition against the instrument itself or it can also mean that optional instruments do not bring sufficient benefits in general. In the latter case, the CESL will face an even bigger obstacle since it will require the businesses to be informed about the legal situation and consequently they will need to take positive actions.

Yet, due to the difficulty of the United Nations to modernise an instrument adopted more than thirty years ago, a European instrument in the field of contract seems to be the most appropriate level to achieve the same objectives. Later on, it has potential to contribute to further international uniformity in collaboration with other regional initiatives. Moreover, it will only complicate the legal environment from a legal perspective. As far as businesses are concerned, the introduction of a European instrument will provide them with an instrument fitted for European ambitions. International businesses can pursue the use of the Convention for almost all their transactions and locally minded firms will not suffer from further interference.

In conclusion, the Convention on the International Sale of Goods diminishes the chances of success of the CESL because of its scope and its experience in the short term. Nevertheless, the CESL has enhanced its likelihood to be relied upon in commercial transactions by implementing the teachings of the CISG and thanks to its more innovative thinking. In the long run, the gap between the needs of the society and the 1980 CISG will continue to grow whereas the modern European Sales Law is best suited for future modifications. Finally, businesses will probably appreciate the convenience of relying on one document regardless of the type of buyer they are selling to. 


\section{Bibliography}

\section{Primary Sources:}

\section{A/CN.9/758}

- United Nations General Assembly, 'Proposal by Switzerland on possible future work in the area of international contract law: Note by the Secretariat', United Nations Commission on International Trade Law $45^{\text {th }}$ session, New York, 8 May 2012, A/CN.9/758.

- Commission Recommendation 2003/361, 6 May 2003, [2003] OJ L 124/36.

\section{CISG-AC Declaration No. 1}

- CISG-AC Declaration No. 1, The CISG and Regional Harmonization, Rapporteur: Professor Michael Bridge, London School of Economics, London, United Kingdom. Adopted by the CISG-AC following its 16th meeting, in Wellington, New Zealand, on Friday, 3 August 2012.

$\operatorname{COM}(2010) 2020$

- Communication from the Commission, 'Europe 2020-A strategy for smart, sustainable and inclusive growth', Brussels 3 March 2010, COM (2010) 2020 final.

$\operatorname{COM}(2010) 348$

- Green Paper from the Commission on policy options for progress towards a European Contract Law, Brussels 1 July 2010, COM (2010) 348 final.

\section{$\operatorname{COM}(2010) 245$}

- Communication from the Commission to the European Parliament, the Council, the European Economic and Social Committee and the Committee for the Regions on A Digital Agenda for Europe, Brussels 26 August 2010, COM (2010) 245 final.

\section{$\operatorname{COM}(2011) 702$}

- Communication from the Commission to the European Parliament, the Council, the European Economic and Social Committee and the Committee of the Regions, 'Small Business, Big World - a new partnership to help SMEs seize global opportunities', Brussels 9 November 2011, COM (2011) 702 final.

- General Assembly Resolution 2205/XXI, 17 December 1966.

- Proposal for a Regulation of the European Parliament and of the Council on a Common European Sales Law, Brussels 11 October 2011, COM (2011) 635 final.

- Regulation (EEC) 2137/85, 25 July 1985, [1985] OJ L1999/1

- Regulation (EC) 2157/2001, 8 October 2001, [2001] OJ L 294/1

- Regulation (EC) 1435/2003, 22 July 2003, [2007] OJ L207/1

- Regulation (EC) 207/2009, 26 February 2009, [2009] OJ L78/1 


\section{Stockholm programme}

- European Parliament resolution of 25 November 2009 on the Communication from the Commission to the European Parliament and the Council - An area of freedom, security and justice serving the citizen - Stockholm programme, 25 November 2009, P7_TA(2009)oogo

UNCITRAL 1992

- UNCITRAL, 'Uniform Commercial Law in the twenty-first century: proceedings of the Congress of the United Nations Commission on International Trade Law', New York, 18-22 May 1992.

- United Nations Convention on the International Sale of Goods, 11 April 1980, Vienna.

- United Nations Convention on the Law of Treaties, 23 May 1969, Vienna.

\section{Case-law:}

- Case 283/81 Srl CILFIT and Lanificio di Gavardo SpA v Ministry of Health [1982] ECR 3429

- Marks \& Spencer PIc v Customs and Excise Commissioners (No.5) [2009] UKHL 8, [2009] 1 All ER 939

\section{Secondary Sources:}

\section{Ben-Shahar 2013}

- O. Ben-Shahar, 'Introduction: A Law and Economics approach to European contract law', 50 Common Market Law Review (2013), pp.3-10.

Bonell 2001

- M.J.Bonell,'Do We Need a Global Commercial Code?', 106 Dickinson Law Review (2001-2002), pp.87-100.

Craig \& de Búrca 2011

- Paul Craig \& Gráinne de Búrca, EU Law - Text, Cases and Materials, (Oxford University Press, 2011).

DiMatteo \& Ostas 2011

- L. A. DiMatteo \& D. T. Ostas, 'Comparative Efficiency in International Sales Law', 26 American University International Law Review 2 (2011), pp.371-439.

\section{Engel \& Stark 2013}

- M. Engel \& J. Stark, 'The CESL as a European Brand: PayPalizing European Contract Law' (April 7, 2013). Available at $h t t p: / / s s r n . c o m / a b s t r a c t=2246271$, last visited on 10 July 2013. 


\section{Foster 2010}

- Nigel Foster, Directions, (Oxford University Press, 2010).

Heidemann 2012

- M. Heidemann, 'European Private Law at the Crossroads: The Proposed European Sales Law', 4 European Review of Private Law (2012), pp.1119-1138.

Herings \& Kanning 2008

- P.J-J.Herings \& A.J. Kanning, 'Harmonization of private law on a global level', 28 International Review of Law and Economics (2008), pp.256-262.

Hesselink 2012a

- M.W. Hesselink, 'How to Opt Into the Common European Sales Law? Brief Comments on the Commission's Proposal for a Regulation', 1 European Review of Private Law (2012), pp.195-212. Hesselink 2012b

- M.W. Hesselink, 'The Case for a Common European Sales Law in an Age of Rising Nationalism', 8 European Review of Contract Law 3 (2012), pp.342-366.

Hondius 2007

- E. Hondius, 'CISG and a European Civil Code: Some Reflexions', 71 Rabels Zeitschrift für ausländisches und internationales Privatrecht (2007), pp.99-114.

Hondius 2011

- E. Hondius, Editorial:'Towards an Optional Common European Sales Law', 6 European Review of Private Law (2011), pp.709-715.

Hondius 2013

- E. Hondius, Editorial: 'Common European Sales Law: If It Does Not Help, It Won't Harm Either(?)', 1 European Review of Private Law (2013), pp.1-12.

Knieper 2006

- R. Knieper, 'Celebrating success by accession to CISG',25 Journal of Law and Commerce (20052006), pp.477-481.

Koehler \& Yujun

- M. F. Koehler \& G. Yujun, 'The Acceptance of the Unified Sales Law (CISG) in Different Legal Systems', 20 Pace International Law Review (2008), pp. 45-60.

Kornet 2012

- N. Kornet, 'The Common European Sales Law and the CISG - Complicating or Simplifying the Legal Environment?', Maastricht European Private Law Institute Working Paper 2012/4 (February 28, 2012). Available at $h t t p: / / s s r n . c o m / a b s t r a c t=2012310$, last visited on 11 July 2013. Kronke 2006

- H. Kronke,'The UN Sales Convention, the UNIDROIT Contract Principles and the way beyond', 25 Journal of Law and Commerce (2005-2006), pp.451-465. 


\section{Lando 2005}

- O. Lando, 'CISG and Its Followers: A Proposal to Adopt Some International Principles of Contract Law', 53 The American Journal of Comparative Law 2 (2005), pp.379-401. Loos 2012

- M. B.M. Loos, 'Commercial sales: the Common European Sales Law compared to the Vienna Sales Convention' (October 19, 2012), Centre for the Study of European Contract Law Working Paper Series No. 2012-014. Available at http://ssrn.com/abstract=2166839, last visited on 14 July 2013.

Low 2012

- G. Low, 'Will firms consider a European optional instrument in contract law', 33 European Journal of Law and Economics 3 (2012), pp.521-540.

Magnus 2010

- U.Magnus, 'The Vienna Sales Convention (CISG) between Civil and Common law - Best of all Worlds', 3 Journal of Civil Law Studies (2010), pp.67-97.

Magnus 2012

- U. Magnus, 'CISG and CESL' (September 1, 2012), Max Planck Private Law Research Paper No. 12/27, in Michael Joachim Bonell, Marie-Louise Holle \& Peter Arnt Nielsen, Liber Amicorum Ole Lando, (Djøf Forlag, 2012), pp. 225-255. Available at http://ssrn.com/abstract=2165758, last visited on 10 July 2013.

Mak 2013

- C. Mak, 'Unweaving the CESL: legal-economic reason and institutional imagination in European Contract Law', 50 Common Market Law Review (2013), pp.277-296.

\section{Mickitz \& Reich 2012}

- H.-W.Mickitz \& N. Reich,'The Commission proposal for a'regulation on a Common European Sales Law (CESL)- Too broad or not broad enough?', EUI Working Papers 2012/04. Available at http://cadmus.eui.eu/bitstream/handle/1814/20485/LAW_2012_04_ERPL_03.pdf, last visited on 13 July 2013.

\section{Moss 2006}

- S.Moss, 'Why the United Kingdom has not ratified the CISG',25 Journal of Law and Commerce (2005-2006), pp.483-485.

\section{Pfund 2012}

- P. H. Pfund, 'Federalism and U.S. participation in intergovernmental efforts to unify private law', 56 Villanova Law Review (2011-2012), pp.559-567.

\section{Posner 2012}

- E. A. Posner, 'The Questionable Basis of the Common European Sales Law: The Role of an Optional Instrument in Jurisdictional Competition' (May 1, 2012), University of Chicago Institute for Law \& Economics Olin Research Paper no. 597. Available at http://ssrn.com/abstract=2049594, last visited on 13 July 2013. 


\section{Rabel 1936}

- Rabel et al., Das Recht des Warenkaufs, Eine rechtsvergleichende Darstellung. 2 Bände, (Tübingen/Berlin, 1936 \& 1957).

Rutgers 2011

- J.W. Rutgers, 'An Optional Instrument on Contract Law and Social Dumping Revisited' (March 8, 2011). Available at $h t t p: / / s s r n . c o m / a b s t r a c t=1780950$, last visited on 10 July 2013.

Sandvik 2012

- B. Sandvik, 'The Battle for the Consumer: On the Relation between the UN Convention on Contracts for the International Sale of Goods and the EU Directives on Consumers Sales', 4 European Review of Private Law (2012), pp.1097-1118.

Schlechtrien 2005

- P. Schlechtriem, 'Basic Structures and General Concepts of the CISG as Models for a Harmonisation of the Law of Obligations', X Juridica International (2005), pp.27-34.

\section{Schwenzer 2012}

- I. Schwenzer,'The Proposed Common European Sales Law and the Convention on the International Sale of Goods', 44 UCC Law Journal (2012), pp.457-481.

\section{Schwenzer \& Hachem 2009a}

- I. Schwenzer \& P. Hachem, 'The CISG - A Story of Worldwide Success,' in J. Kleinemann, CISG Part II Conference (Stockholm, 2009), pp.119-140.

Schwenzer \& Hachem 2009b

- I. Schwenzer \& P. Hachem, 'The CISG - Successes and Pitfalls', 57 American Journal of Comparative Law (2009), pp.457-478.

\section{Smits 2010}

- J. Smits, 'Optional Law: A Plea for Multiple Choice in Private Law', Maastricht Journal of 17 European and Comparative Law (2010), pp.347-352.

Smits 2012

- J. Smits,'The Common European Sales Law (CESL): Beyond Party Choice', Maastricht European Private Law Institute Working Paper No. 2012/11 (April 1, 2012). Available at http://ssrn.com/abstract=2039345, last visited on 13 July 2013.

Smits 2013

- J. Smits, 'Party Choice and the Common European Sales Law, or: How to prevent the CESL from becoming a lemon on the law market', 50 Common Market Law Review (2013), pp.51-68.

Vogenauer \& Weatherill 2006

- S. Vogenauer \& S. Weatherill, 'The European Community's competence to Pursue the Harmonisation of Contract Law: An Empirical Contribution to the Debate', in Stefan Vogenauer \& Stephen Weatherill, The Harmonisation of European Contract Law: Implications for European Private Laws, Business and Legal Practice, (Hart Publishing, 2006). 


\section{Whited 2012}

- C.M. Whited, 'The UNIDROIT Principles of International Commercial Contracts: An overview of their utility and the role they have played in reforming domestic contract law around the world', 18 ILSA Journal of International and Comparative Law (2011-2012), pp. 167-192.

\section{Whittaker 2013}

- S. Whittaker, 'Identifying the legal costs of operation of the Common European Sales Law', 50 Common Market Law Review (2013), pp.85-108.

\section{Internet Sources:}

\section{Allen \& Overy 2013}

- Allen \& Overy, 'A Common European Sales Law (CESL): An update on the European Commission's ambitious plans', January 2013. Available at http://www.allenovery.com/SiteCollectionDocuments/CESL.pdf, last visited on 10 July 2013.

Bull 2011

- W. Bull, Conference Report: 'The Proposed Common European Sales Law: Have the Right Choices Been Made?' in Brussels, Belgium, 9 December 2011, 2 European Review of Private Law (2012), p.649-653.

\section{CCBE 2012}

- Council of Bars and Law Societies of Europe (CCBE), 'CCBE Position Paper on the proposal for a Regulation on a Common European Sales Law (COM(2011)0635)', September 2012. Available at http://www.ccbe.eu/fileadmin/user_upload/NTCdocument/07092012_EN_ CCBE_POS1_1347546312.pdf, last visited on 13 July 2013.

\section{CISG Advisory Council}

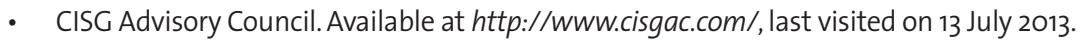

\section{CISG Database}

- CISG Database Pace University. Available at $h t t p: / / w w w . c i s g . l a w . p a c e . e d u$, last visited on 13 July 2013.

\section{CLOUT}

- CLOUT database (Case Law on UNCITRAL Texts). Available at http://www.uncitral.org/uncitral/en/case_law.html, last visited on 13 July 2013.

\section{CLEPA November 2012}

- CLEPA European Association of Automotive Suppliers, 'CLEPA Position on a Common European Sales Law', November 2012. Available at http://gallery.mailchimp.com/21d3beffd804coe712302d292/files/CLEPA_CESL_position.pdf, last visited on 13 July 2013. 


\section{European Commission - Green Paper}

- European Commission, 'Green Paper from the Commission on policy options for progress towards a European Contract Law (ECL)'. Last updated on 3-2-2012. Available at http://ec.europa.eu/justice/newsroom/contract/opinion/100701_en.htm, last visited on 11 July 2013.

\section{European Commission - Enterprise}

- European Commission, 'Fact and figures about the EU's Small and Medium Enterprise (SME)'. Last update 4-2-2013. Available at

http://ec.europa.eu/enterprise/policies/sme/facts-figures-analysis/, last visited on 10 July 2013.

European Commission - Justice

- European Commission, 'Green Paper on policy options for progress towards a European Contract Law (ECL)'. Last update 3-2-2012. Available at

http://ec.europa.eu/justice/newsroom/contract/opinion/100701_en.htm, last visited on 11 July 2013.

European Law Institute 2012

- European Law Institute (ELI), Statement of the European Law Institute on the Proposal for a Regulation on a Common European Sales Law COM(2011) 635 final, (European Law Institute, 2012).

\section{Flash Eurobarometer 2011a}

- European Commission, 'European contract law in business-to-business transactions: Analytical Report', Flash Eurobarometer EB 320, 2011. Available at

http://ec.europa.eu/public_opinion/flash/fl_320_sum_en.pdf, last visited on 13 July 2013.

Flash Eurobarometer 2011b

- European Commission, 'European contract law in consumer transactions: Analytical Report', Flash Eurobarometer EB 321, 2011. Available at http://ec.europa.eu/public_opinion/flash/fl_321_sum_en.pdf, last visited on 14 July 2014.

ICC Commission on Commercial Law and Practice 2012

- ICC Commission on Commercial Law and Practice 2012, 'ICC Position on the European Commission proposal for a regulation on a Common European Sales Law', Document No 460/662, July 2012. Available at

http://www.iccwbo.org/Advocacy-Codes-and-Rules/Document-centre/2012/ICC-Position-onthe-EC-proposal-for-a-Common-European-Sales-Law/, last visited on 10 July 2013.

IPYME 2003

- IPYME,'Definición de PYME'. Available at http://Www.ipyme.org/ES-ES/CREACIONEMPRESAS/Paginas/DefiniciondePYME.aspx, last visited on 14 July 2013. 
James 17-12-2012

- S. James, Speech at the CCBE debate on the proposed Common European Sales Law, Brussels, 17 December 2012. Available at

http://www.ccbe.eu/fileadmin/user_upload/document/CESL_conference/James_speech.pdf, last visited on 13 July 2013.

JURI 2013

- JURI Report February 2013, Issue No 2, pp.1-13. Available at http://www.europarl.europa.eu/ document/activities/cont/201302/20130214ATT61055/20130214ATT61055EN.pdf, last visited on 13 July 2013.

Law Commission \& Scottish Law Commission 2011

- The Law Commission and the Scottish Law Commission, An Optional Common European Sales Law: Advantages and Problems: Advice to the UK Government', November 2011. Available

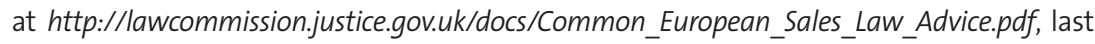
visited on 13 July 2013.

Law Society of England and Wales 2012

- Law Society of England and Wales, 'Common European Sales Law: Response to UK Government Call for Evidence', May 2012. Available at http://www.barcouncil.org.uk/ media/159762/barcouncilof_england__wales_response_to_moj_bis_call_on_cesl__ may2012final.pdf, last visited on 13 July 2013.

Magnus 2003

- U.Magnus, 'Action Plan for a European Contract Law: European Contract Law and CISG', Public Consultation 2003, Contribution 5-35. Available at http://ec.europa.eu/consumers/cons_int/ safe_shop/fair_bus_pract/cont_law/stakeholders/5-35.pdf, last visited on 11 July 2013.

Ministère de l'Economie et des Finances 2012

- Ministère de l'Economie et des Finances, 'Comment definit-on les petites et les moyennes entreprises?', last updated in 2012. Available at

http://Www.economie.gouv.fr/cedef/definition-petites-et-moyennes-entreprises, last visited on 14 July 2013.

Monti 2010

- M. Monti, 'A New Strategy for the Single Market -At the Service of Europe's Economy and Society', August 2010. Available at:

http://ec.europa.eu/bepa/pdf/monti_report_final_10_05_2010_en.pdf, last visited on 13 July 2013.

Oxford Institute 2008

- Oxford Institute of European and Comparative Law and the Oxford Centre for Socio-LegalStudies, 'Civil Justice Systems in Europe: final results', 2008. Available at http://denning. law.ox.ac.uk/iecl/pdfs/Oxford\%20Civil\%20Justice\%20Survey\%20-\%20Summary\%200f\%20 Results,\%20Final.pdf, last visited on 14 July 2013. 


\section{Popham 2005}

- Stuart Popham, Clifford Chance Survey in European Contract Law, (Clifford Chance, 2005). Reding 6-3-2012

- V. Reding, Speech/12/164: 'The Common European Sales Law - breaking the mould to help businesses and customers', Realising the European Single Market Forum 2012, Brussels, 6-32012. Available at http://europa.eu/rapid/press-release_SPEECH-12-164_en.htm, last visited on 14 July 2013.

Reding 17-12-2012

- V. Reding, Speech/12/962: 'The Common European Sales Law - a useful tool for business', CCBE debate on the proposed Common European Sales Law, Brussels, 17-12-2012. Available at http://europa.eu/rapid/press-release_SPEECH-12-962_en.htm, last visited on 13 July 2013.

Schulze 17-12-2012

- R. Schulze, Speech:'What Scholars say: A Commentary on CESL', CCBE debate on the proposed Common European Sales Law, Brussels, 17-12-2012. Available at

http://www.ccbe.eu/fileadmin/user_upload/document/CESL_conference/schulze_speech.pdf, last visited on 13 July 2013.

\section{Sciaudone 2012}

- F. Sciaudone, Briefing note: 'Proposal for a Regulation on a Common European Sales Law: a lawyer's viewpoint', European Parliament, Directorate General for Internal Policies, PE 462.472, 2012. Available at $h t t p: / / w w w . e u r o p a r l . e u r o p a . e u / d o c u m e n t / a c t i v i t i e s / c o n t / 201210$ /20121019ATT54056/20121019ATT54056EN.pdf, last visited on 13 July 2013.

\section{Scottish Law Commission 1993}

- Scottish Law Commission, 'Report on Formation of Contracts: Scottish Law and the United Nations Convention on Contracts for the International Sale of Goods', Scottish Law Commission No. 144, 1993.

UEAPME 2001

- UEAPME, Position paper: 'UEAPME position paper on the European Commission's Communication on European Contract Law', October 2001. Available at http://ec.europa.eu/consumers/cons_int/safe_shop/fair_bus_pract/cont_law/comments/2.5.4.pdf, last visited on 13 July 2013.

UEAPME 2012a

- UEAPME, Position Paper: 'UEAPME position on the Proposal for a Regulation of the European Parliament and of the Council on a Common Sales Law (COM(2011)635 final) (general remarks)', January 2012. Available at $h t t p: / / w w w$. ueapme.com/IMG/pdf/120119_pp_General_ Remarks_CESL.pdf, last visited on 13 July 2013. 


\section{UEAPME $2012 b$}

- UEAPME, Position Paper:'UEAPME position on the Proposal for a Regulation of the European Parliament and of the Council on a Common Sales Law (COM(2011)635 final) (specific remarks)', January 2012. Available at $h t t p: / / W w w$. ueapme.com/IMG/pdf/120119_pp_Specific_ Remarks_CESL.pdf, last visited on 13 July 2013.

\section{UEAPME 2012c}

- UEAPME, Updated Position Paper: 'UEAPME position on the Proposal for a Regulation of the European Parliament and of the Council on a Common Sales Law (COM(2011)635 final)', November 2012. Available at http://www.ueapme.com/IMG/pdf/UEAPME_pp_CESL_Nov_2012.pdf, last visited on 13 July 2013.

\section{UEAPME 2013}

- UEAPME, Position Paper:'UEAPME position on the draft report of the Legal Affairs Committee on the Proposal for a Regulation of the European Parliament and of the Council on a Common Sales Law for the European Union (COM(2011)0635 - C7-0329/2011 - 2011/0284(COD))', April 2013. Available at

http://www.ueapme.com/IMG/pdf/UEAPME_Position_Paper_on_CESL_Draft_Report.pdf, last visited on 13 July 2013.

Usunier et al. 2011a

- Laurence Usunier et al., Réponse au Livre vert de la Commission relative aux actions envisageables en vue de la creation d'un droit européen des contrats pour les consommateurs et les entreprises du 1er juillet 2010, (Trans Europe Experts, 2011).

Usunier et al. 2011b

- L. Usunier et al.; 'Réponse au Livre vert de la Commission relative aux actions envisageables en vue de la creation d'un droit européen des contrats pour les consommateurs et les entreprises: aspects de droit international privé' in Martine Behar-Touchais \& Muriel Chagny, Livre vert sur le droit européen des contrats - Réponse du Réseau Trans Europe Experts, (Trans Europe Experts, 2011).

Webster 22-10-2012

- D. Webster interviewed by K. Beaumont, 'How far will a Common European Sales Law facilitate cross-border trade?', 22-10-2012. Available at

http://www.russell-cooke.co.uk/clientUpload/document/file/How\%20far\%20will\%20a\%20 Common\%20European\%20Sales\%2OLaw\%20facilitate\%2Ocross-border\%20trade\%20-\%20 Lexis\%2ONexis\%20-\%20November\%202012.pdf, last visited on 13 July 2013. 


\section{Websites}

Service Public Fédéral Belge 2010

- Service Public Fédéral Belge, 'Connaissances en gestion', last updated in 2010. Available at http://www.belgium.be/fr/economie/entreprise/creation/etapes_principales/connaissance_ en gestion/, last visited on 14 July 2013.

\section{UNCITRAL- CISG}

- United Nations Commission on International Trade Law,'1980 - United Nations Convention on Contracts for the International Sale of Goods (CISG)'. Available at http://www.uncitral.org/uncitral/uncitral_texts/sale_goods/1980CISG.html, last visited on 10 July 2013.

\section{UNCITRAL-CISG Status}

- United Nations Commission on International Trade Law,'1980 - United Nations Convention on Contracts for the International Sale of Goods (CISG) - Status'. Available at http://www.uncitral.org/uncitral/en/uncitral_texts/sale_goods/1980CISG_status.html, last visited on 10 July 2013.

\section{UNCITRAL - Electronic Commerce Status}

- United Nations Commission on International Trade Law, '2005 - United Nations Convention on the Use of Electronic Communications in International Contracts - Status'. Available at http://www.uncitral.org/uncitral/en/uncitral_texts/electronic_commerce/2005Convention status.html, last visited on 11 July 2013.

United Nations - Member States

- United Nations, 'Member States of the United Nations'. Available at http://www.un.org/en/members/index.shtml, last visited on 11 July 2013. 